\title{
Detection of Cadmium Risk to the Photosynthetic Performance of Hybrid Pennisetum
}

\author{
Xiliang Song ${ }^{1,2}$, Xian Yue ${ }^{1}$, Weifeng Chen ${ }^{1,2 *}$, Huixin Jiang ${ }^{3}$, Yanyun Han ${ }^{1}$ and Xu $\mathrm{Li}^{1}$ \\ ${ }^{1}$ College of Resources and Environment, Shandong Agricultural University, Tai'an, China, ${ }^{2}$ Shandong Provincial Engineering \\ and Technology Research Center for Phyto-Microremediation in Saline-Alkali Land, Shandong, China, ${ }^{3}$ Shandong Provincial \\ Animal Husbandry General Station, Shandong Province Grass Products Quality Inspection Center, Jinan, China
}

Photosynthesis plays an essential role in plant growth and crop yield, and the mechanisms of the effects of cadmium (Cd) on photosynthetic performance require more attention. The acute toxicity of $\mathrm{Cd}$ in soil to the photosynthetic capacity of Hybrid Pennisetum was evaluated using gas exchange parameters, $A / C_{i}$ curves, light response curves, and chlorophyll a fluorescence transients after exposure to elevated Cd concentrations $\left(0,10,20,50,70\right.$, and $\left.100 \mathrm{mg} \mathrm{kg}^{-1}\right)$ for a 3-month period. The results indicated that leaf $\mathrm{Cd}$ concentration in Hybrid Pennisetum increased with the strength of soil Cd stress and ranged from 4.9 to $15.8 \mu \mathrm{g} \mathrm{g}^{-1} \mathrm{DW}$. The accumulation of leaf $\mathrm{Cd}$ severely restricted photosynthesis and its non-stomatal limitation in regulating the photosynthetic performance of Hybrid Pennisetum. The leaf chloroplasts at 10 and $20 \mathrm{mg} \mathrm{kg}^{-1} \mathrm{Cd}$ concentrations showed no noticeable change, but the chlorophyll content significantly decreased by $9.0-20.4 \%$ at $50-100 \mathrm{mg} \mathrm{kg}^{-1}$ $\mathrm{Cd}$ concentrations. The $\mathrm{Cd}$ treatments also decreased plant ribulose-1,5-bisphosphate (RuBP) activity $\left(V_{c \max }\right)$ and regeneration capacity $\left(J_{\max }\right)$, triose phosphate utilization (TPU), light-saturated photosynthesis $\left(A_{\text {max }}\right)$, apparent quantum yield (AQY), light saturation point $(L S P)$, and dark respiration $\left(R_{\text {day }}\right)$, but $\mathrm{Cd}$ treatment increased the light compensation point $(L C P)$. The shape of chlorophyll a fluorescence transients in leaves was altered under different Cd treatments. The increased OJ phase and the decreased IP phase in fluorescence induction curves suggested that Cd toxicity inhibited both light use efficiency and photodamage avoidance ability. These results suggested that the decrease in photosynthesis through exposure to $\mathrm{Cd}$ may be a result of the decrease in leaf chlorophyll content, Rubisco activity, and RuBP regeneration, inhibition of triose phosphate utilization, reduction of the ability to use light and provide energy, and restrictions on electron transport in PSII.

Keywords: cadmium stress, photosynthetic performance, electron transport, non-stomatal limitation, Hybrid Pennisetum

\section{INTRODUCTION}

With the increasing anthropogenic activities of phosphate fertilizer abuse and sewage sludge, herbicide and pesticide application, excessive industrial and aquaculture wastewater for being used for irrigation, as well as a high frequency of mining and smelting, contaminated soil polluted by heavy metals is attracting increasing attention worldwide (Mcintyre, 2003; Rizwan et al., 2017). 
Cadmium (Cd), as one of the most harmful heavy metals in soils, has been widely accepted to be an extremely dangerous pollutant due to its acute toxicity, high water solubility, non-degradability, and persistence inside most live organisms (Ghosh and Singh, 2005; Groppa et al., 2012; Parmar et al., 2013). Studies have found that Cd can be more easily taken up by many plant species than most other heavy metals (Gallego et al., 2012; Yu et al., 2017). Excessive accumulation of $\mathrm{Cd}^{2+}$ in plant tissues could cause serious phytotoxicity (Groppa et al., 2007) and numerous morphological, physiological, and biochemical toxic effects on plant growth and development (Lutts and Lefèvre, 2015; Wali et al., 2015), such as destroying leaf chlorophyll structure (Santos et al., 2018), depressing photosynthesis and respiration (Hendrik et al., 2010; Lee et al., 2010; Zhang et al., 2015), disturbing the uptake and translocation of mineral nutrients (Erdal and Turk, 2016), accumulating reactive oxygen species (ROS) (Gallego et al., 2012), restraining protein synthesis and enzymatic activity (Fornazier, 2002; Wu et al., 2015), dwarfing plants (Rascio et al., 2008), inhibiting the growth of roots (Vartika et al., 2005), decreasing biomass (Rascio et al., 2008), and even leading to plant death if $\mathrm{Cd}$ exceeds their resistance values (Clemens et al., 2013; Shanying et al., 2017).

Among all the physiological and biochemical processes in plants, photosynthesis, as a central carbon anabolic pathway providing energy-rich organic compounds, plays an essential role in maintaining the equilibrium between the light energy absorbed by photosystems and the chemical energy consumed by metabolic sinks (Brestic et al., 2015). The efficiency of photosynthesis has a direct relationship with plant growth and development (Kalaji et al., 2017). Photosynthesis is also a process that is highly sensitive to any changes in environmental conditions. Actually, it has been proven to be a primary target of inhibition caused by metal-induced stress (Joshi and Mohanty, 2004). Any structural and functional alterations in the photosynthetic apparatus will adversely affect physiological activities and likely affect plant growth and survival (Baek et al., 2004). Therefore, a deep understanding of the responses of plant photosynthetic performance to heavy metal stress is necessary to scientifically address the problems of soil contamination.

The deleterious effects of $\mathrm{Cd}$ stress on photosynthetic attributes occur in various ways. Cd stress inhibits the biosynthesis of chlorophylls (Stephen et al., 2007; Shukla et al., 2008) and their stable binding to proteins (Horváth et al., 1996), causing stomatal opening (Sandalio et al., 2001), damaging light-harvesting complex II and photosystems (Hendrik et al., 2010), decreasing the transcription of photosynthesis-related genes such as psbA, psaB, and rbcL (Qian et al., 2009), thereby inducing a considerable reduction in the quantum yields of both photosystem I (PSI) and photosystem II (PSII) and the electron transport rate and slowing down the net photosynthetic rate (Goussi et al., 2018). PSII of photosynthesis is the primary target of Cd toxicity (Alexander et al., 2008; Popova et al., 2009). Cadmium may arrest the photosynthetic electron flow (Voigt and Nagel, 2002), inhibit the water-splitting complex of the oxidizing site of PS II (Nirupama and Mohn, 2003), or competitively bind to the essential $\mathrm{Ca}^{2+}$ site in PSII during photoactivation (Faller et al., 2005). Furthermore, Cd has also been shown to inhibit energy utilization and carbon sequestration by slowing down the activity of various enzymes, such as ribulose-1,5-bisphosphate (RuBP) carboxylase oxygenase (Mobin and Khan, 2007), phosphoenolpyruvate carboxylase (Alexander et al., 2008), aldolase (Sheoran et al., 1990), fructose-6-phosphate kinase (Malik et al., 1992), fructose-1,6-bisphosphatase (Sheoran et al., 1990), $\mathrm{NADP}^{+}$-glyceraldehyde-3-phosphate dehydrogenase (Sheoran et al., 1990), and carbonic anhydrase (Mobin and Khan, 2007).

Although great progress has been made in understanding the Cd hazard to plant photosynthetic performance ( $\mathrm{Li}$ et al., 2013), the effects of Cd ions on photosynthetic performance varied with different $\mathrm{Cd}$ concentrations, plant species, and stress tolerance degrees (Ghnaya et al., 2005; Mobin and Khan, 2007; Wali et al., 2016, 2017). Therefore, the disturbance mechanisms of $\mathrm{Cd}$ on photosynthesis still need to be studied further. Hybrid Pennisetum is a high-stalk perennial grass and is widely planted in south China for the remarkable advantages in fast growth, high biomass, and high ability in endure adverse stress conditions. However, the $\mathrm{Cd}$ risk to Hybrid Pennisetum has seldom been explored. The aims of this work were to explore the changes in photosystem efficiency and photosynthetic activity in the leaves of Hybrid Pennisetum treated with different amounts of $\mathrm{Cd}$. In the present study, leaf gas exchange parameters, light response curves, $\mathrm{CO}_{2}$ response curves, and chlorophyll $a$ fluorescence transients were determined to examine the photosynthetic responses of Hybrid Pennisetum to soil Cd stress.

\section{MATERIALS AND METHODS}

\section{Plant Material and Growth Conditions}

The pot experiment was conducted in a greenhouse at the Experimental Station of Shandong Agricultural University, Tai'an, China $\left(36^{\circ} 09^{\prime} \mathrm{N}, 117^{\circ} 09^{\prime} \mathrm{E}\right)$. Growing conditions in the greenhouse were maintained as follows: $27 / 22^{\circ} \mathrm{C}$ temperature (day/night), a $14 \mathrm{~h}$ photoperiod per day, $65-75 \%$ relative humidity, and $1000 \mathrm{~mol} \cdot \mathrm{m}^{-2}$ day $^{-1}$ of average daily photosynthetically active radiation (PAR).

The seeds of Hybrid Pennisetum (cv. Ningza NO. 4), kindly provided by Shandong Provincial Animal Husbandry General Station, were used in this study. Healthy seeds were surface-sterilized in $10 \% \mathrm{H}_{2} \mathrm{O}_{2}$ for $10 \mathrm{~min}$ and cleaned with sterile deionized water three times. Seeds were then sown in plastic pots ( $8 \mathrm{~cm}$ in height, $10 \mathrm{~cm}$ in diameter) containing soil composed of peat and vermiculite $(4: 1$, w/w) mixed with sand $(3: 1, w / w)$ for germination.

\section{Experimental Designs}

Six treatments $\left(0,10,20,50,70\right.$, and $\left.100 \mathrm{mg} \cdot \mathrm{kg}^{-1} \mathrm{Cd}\right)$ with four replicates were set up and designated as $\mathrm{Cd} 0, \mathrm{Cd} 10$, Cd20, Cd50, Cd70, and Cd100, respectively. Each plastic pot (40 $\mathrm{cm}$ in height and $48 \mathrm{~cm}$ in diameter) was filled with 
$20.0 \mathrm{~kg}$ of air-dried soil (sieved through $2 \mathrm{~cm} \mathrm{mesh}$ ) that was retrieved from the local surface soil $(0-20 \mathrm{~cm})$ and then saturated with a heavy metal solution containing the required amount of $\mathrm{CdCl}_{2} \cdot 2.5 \mathrm{H}_{2} \mathrm{O}$. The soil basic physical and chemical properties were as follows: soil texture of $73.8 \%$ sand, $12.1 \%$ silt, and $14.1 \%$ clay, soil $\mathrm{pH}$ of 6.67 , organic matter of $13.52 \mathrm{~g} \mathrm{~kg}^{-1}$, available $\mathrm{Cd}$ concentration of $0.08 \mathrm{mg} \mathrm{kg}^{-1}$, total nitrogen of $75.62 \mathrm{mg} \mathrm{kg}^{-1}$, available phosphorus of $67.38 \mathrm{mg} \mathrm{kg}^{-1}$, and available potassium of $80.12 \mathrm{mg} \mathrm{kg}$. After the third leaf emerged (approximately 2 weeks after sowing), five uniform seedlings were transferred to Cd-treated plastic pots. All pots were watered each day to keep the soil moisture at $75-85 \%$ with deionized water. To avoid nutrient deficiency, the soil was supplied with urea $\left(0.20 \mathrm{~g} \mathrm{~N} \mathrm{~kg}^{-1}\right)$, diammonium phosphate $\left(0.15 \mathrm{~g} \mathrm{P}_{2} \mathrm{O}_{5} \mathrm{~kg}^{-1}\right)$ and potassium sulfate $\left(0.20 \mathrm{~g} \mathrm{~K}_{2} \mathrm{O} \mathrm{kg} \mathrm{kg}^{-1}\right)$ as basal fertilizers in each pot. All the following measurements were conducted after three months of plant growth with $\mathrm{Cd}$ treatments. Each plant was tested starting from the treatment of $\mathrm{Cd} 0-\mathrm{Cd} 100$ and again starting from the treatment of $\mathrm{Cd} 0$ to reduce the differences caused by the determination time.

\section{Chlorophyll Content Measurements}

The SPAD values of chlorophyll were determined with a portable chlorophyll meter (SPAD-502, Osaka 590-8551, Japan). Leaf samples were obtained from new and fully expanded leaves from the tip, with 15 plant replicates for each treatment.

\section{Gas Exchange Measurements}

The second fully expanded young leaves from the tops of the plants were used to estimate the net photosynthetic rate $\left(P_{n}\right)$, stomatal conductance $\left(G_{s}\right)$, intercellular $\mathrm{CO}_{2}$ concentration $\left(C_{i}\right)$, transpiration rate $\left(T_{r}\right)$, and water use efficiency $\left(W U E=P_{n} / T_{r}\right)$ using a portable photosynthesis system (CIRAS-3, PP-system, Hitchin, United Kingdom). The experiment was performed on sunny days from 9:00 to 11:00 am and 14:00 to 16:00 pm. The illumination was supplied to the leaves from a red-blue LED light source. Leaf chamber temperature was maintained at room temperature with $\mathrm{a} \mathrm{CO}_{2}$ concentration of $390 \mathrm{ppm}$ and a photosynthetic photon flux density (PPFD) of $1000 \mathrm{~mol}$ photon $\cdot \mathrm{m}^{-2} \cdot \mathrm{s}^{-1}$. These measurements were performed on three plants in each Cd treatment.

\section{Light Response Curves}

Light response curves were measured in the same leaf that was chosen for gas exchange parameter measurement with a portable photosynthesis system (CIRAS-3, PP-system, Hitchin, United Kingdom) under constant leaf temperature $\left(25^{\circ} \mathrm{C}\right)$ and $\mathrm{CO}_{2}$ concentration $\left(390 \mathrm{~mol} \cdot \mathrm{mol}^{-1}\right)$. The leaves were placed under $300 \mathrm{~mol}$ photon $\cdot \mathrm{m}^{-2} \cdot \mathrm{s}^{-1}$ for $15 \mathrm{~min}$ to fully activate the photosynthesis systems. The light series of photosynthetic light flux density were set as follows: 1600, 1200, 800, 600, $400,200,150,100,50$, and $0 \mathrm{~mol}$ photon $\cdot \mathrm{m}^{-2} \cdot \mathrm{s}^{-1}$. All of the measurements were carried out from 9:00 to 11:00 am and 14:00 to $16: 00 \mathrm{pm}$ on sunny days. Three plants were measured each time.
The responses of net photosynthetic rate to different light levels were modeled using the non-rectangular hyperbola in the Farquhar model (Prioul and Chartier, 1977):

$$
\begin{aligned}
& P_{n}(I)= \\
& \frac{A Q Y^{*} I+A_{\max } \sqrt{\left(A Q Y^{*} I+A_{\max }\right)^{2}-4 A Q Y^{*} \theta^{*} I^{*} A_{\max }}}{2 \theta}-R_{d}
\end{aligned}
$$

where $P_{n}$ is the net photosynthetic rate $\left(\mu \mathrm{mol} \cdot \mathrm{CO}_{2} \mathrm{~m}^{-2} \cdot \mathrm{s}^{-1}\right)$, $A_{\max }$ is the light-saturated rate of $\mathrm{CO}_{2}$ accumulation $\left(\mu \mathrm{mol} \cdot \mathrm{CO}_{2} \mathrm{~m}^{-2} \cdot \mathrm{s}^{-1}\right), I$ is the photosynthetic photon flux density $\left(\mu \mathrm{mol} \cdot \mathrm{m}^{-2} \cdot \mathrm{s}^{-1}\right), A Q Y$ is the leaf maximum apparent quantum yield of $\mathrm{CO}_{2}$ uptake, $\theta$ is the convexity of the light response curve, and $R_{d}$ is the dark respiration $\left(\mu \mathrm{mol} \cdot \mathrm{m}^{-2} \cdot \mathrm{s}^{-1}\right)$. The quantum yield could be estimated from the initial slope by fitting linear regression to the low-photon flux data (less than $200 \mu \mathrm{mol} \cdot \mathrm{m}^{-2} \cdot \mathrm{s}^{-1}$ ) of the light response curve. The intersection point of the straight line with the $X$-axis corresponded to $L C P$ (the light compensation point, $\mu \mathrm{mol} \cdot \mathrm{m}^{-2} \cdot \mathrm{s}^{-1}$ ). The projection of $A_{\max }$ to the $X$-axis corresponded to LSP (the light saturation point, $\left.\mu \mathrm{mol} \cdot \mathrm{m}^{-2} \cdot \mathrm{s}^{-1}\right)$.

\section{$A / C_{i}$ Curves}

In the same leaves, the response of light-saturated $\mathrm{CO}_{2}$ assimilation to variable internal $\mathrm{CO}_{2}$ concentrations $\left(A / C_{i}\right.$ curves) was measured as described in Guidi et al. (2008). $P_{n}$ was measured at $\mathrm{CO}_{2}$ concentrations of 50, 100, 200, 300, $360,400,600,800,1000,1300,1600$, and $2000 \mathrm{~mol} \cdot \mathrm{mol}^{-1}$ at photosynthesis saturating irradiance $400 \mathrm{~mol} \cdot$ photon $\cdot \mathrm{m}^{-2} \cdot \mathrm{s}^{-1}$. From the $A / C_{i}$ curves, the following photosynthetic parameters were calculated according to Long and Bernacchi (2003): maximum carboxylation $\left(V_{\text {cmax }}\right)$, maximum rate of RuBP regeneration $\left(J_{\max }\right)$, and triose phosphate utilization $(T P U)$. A buffer bottle was used to control the concentrations of $\mathrm{CO}_{2}$.

\section{Measurements of Leaf OJIP Transients}

The fast $\mathrm{Chl}$ fluorescence induction kinetics curve was measured using a Handy-PEA chlorophyll fluorometer (Hansatech, United Kingdom). The leaves used to measure the net photosynthetic rate were dark-adapted for $30 \mathrm{~min}$ before determination of the minimal $\left(F_{0}\right)$ and maximal $\left(F_{m}\right)$ fluorescence yields. The fluorescence intensity was measured from $20 \mu \mathrm{s}$ (initial fluorescence $F_{0}$ ) to $1 \mathrm{~s}$. Biolyzer HP3 software (Bioenergetics Lab., Geneva, Switzerland) was used to analyze the energy pipeline models and specific energy fluxes.

\section{Determination of Leaf Cd Content}

Leaf samples were washed with deionized water and oven-dried at $105^{\circ} \mathrm{C}$ for $30 \mathrm{~min}$ and then $75^{\circ} \mathrm{C}$ until a constant weight was achieved and maintained. A ground sample of $0.250 \mathrm{~g}$ was microwave-digested (CEM, MARS5, United States) with $8 \mathrm{~mL}$ of $\mathrm{HNO}_{3}$ at $180^{\circ} \mathrm{C}$ for $30 \mathrm{~min}$. Then, the leaf $\mathrm{Cd}$ concentration was determined by ICP-MS (Agilent ICP-MS 7700ce, Agilent Technologies, Santa Clara, CA, United States). 


\section{Statistics Analysis}

All of the parameters described above were measured 90 days after the plants were subjected to soil $\mathrm{Cd}$ treatments. SPSS 19.0 statistical software package (SPSS, Chicago, IL, United States) were used in the study to perform the statistical analyses. For each treatment, the mean values with standard deviation $( \pm S D)$ are shown in the figures and tables. The parameters were analyzed by one-way analysis of variance (ANOVA, $p<0.05$ ), followed by Duncan's multiple range tests. The graphs were created using Origin 9.0 software (Origin Lab, United States).

\section{RESULTS}

\section{Cd Contents in Leaves}

The Cd concentration in leaves of Hybrid Pennisetum exhibited remarkable differences among various $\mathrm{Cd}$ soil treatments (Figure 1). In the low soil Cd treatments (Cd10 and Cd20), the $\mathrm{Cd}$ concentration in leaves ranged from 4.9 to $15.8 \mu \mathrm{g} \mathrm{g}^{-1}$. With the increase in $\mathrm{Cd}$ added into the soil, the $\mathrm{Cd}$ concentration in leaves showed a sharp increase. At Cd100, the Cd concentration in leaves reaches $86.4 \mu \mathrm{g} \mathrm{g}^{-1}$, which is approximately 20 times higher than the $\mathrm{Cd}$ concentration in leaves from the Cd10 treatment.

\section{SPAD Values in Leaves}

The SPAD chlorophyll values of Hybrid Pennisetum are shown in Figure 2. Compared to $\mathrm{Cd} 0$, the chlorophyll values of the leaves in Hybrid Pennisetum were not influenced by 10 to $20 \mathrm{mg} \mathrm{kg}^{-1}$ of $\mathrm{Cd}^{2+}$ pollution. With the increase in Cd added to the soil, the SPAD chlorophyll values significantly decreased. Compared to $\mathrm{Cd} 0$ plants, the SPAD values of Cd50, Cd70, and Cd100 plants decreased by $9.0,9.6$, and $20.4 \%$, respectively.

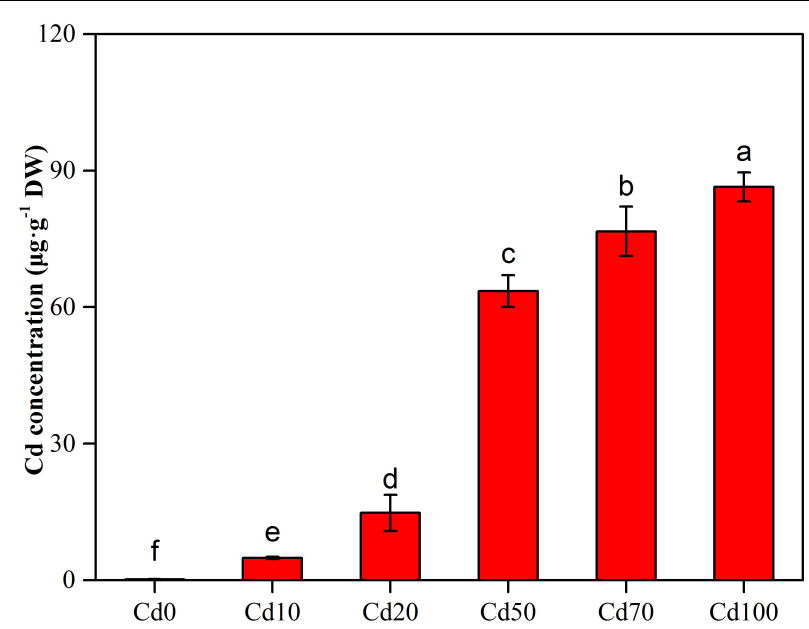

FIGURE 1 | Effect of different concentrations of Cd concentration in leaves of Hybrid Pennisetum. Vertical bars represent \pm SD of the mean $(n=3)$; different letters on the SD bars indicate significant differences among the $\mathrm{Cd}$ treatments $(p<0.05)$.

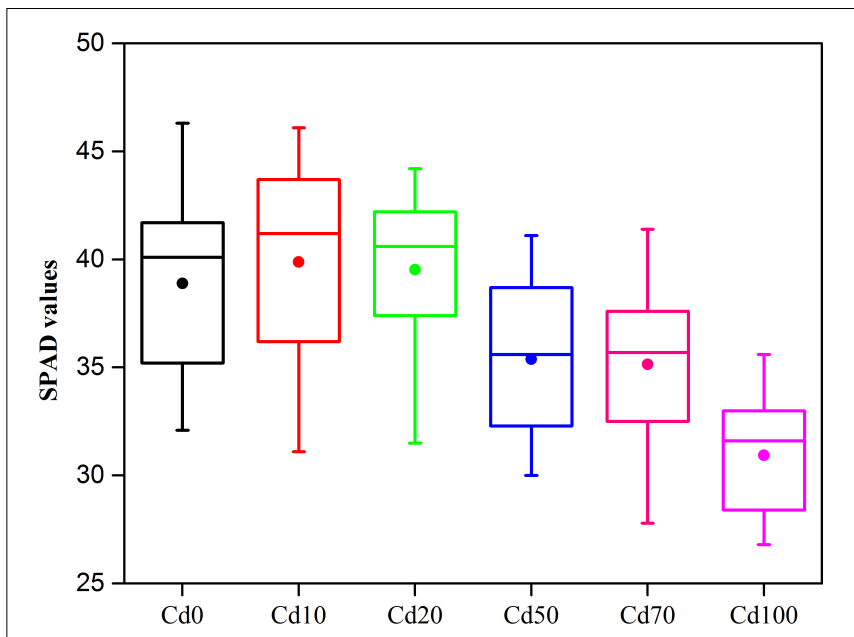

FIGURE 2 | Boxplots of SPAD under different Cd stress. The solid circle in the box plots represents the mean values, $n=15$.

\section{Gas Exchange Parameters}

Instantaneous gas exchange parameters corresponding to plants subjected to different soil Cd treatments are presented in Figures 3A-E. The maximum values of net $\mathrm{CO}_{2}$ assimilation rate $\left(P_{n}\right.$, Figure $\left.3 \mathbf{A}\right)$, stomatal conductance $\left(G_{s}\right.$, Figure $\left.3 \mathbf{B}\right)$, and water use efficiency ( $W U E$, Figure $3 \mathrm{E}$ ) found in $\mathrm{Cd} 0$ were $13.4 \mu \mathrm{mol} \cdot \mathrm{CO}_{2} \mathrm{~m}^{-2} \cdot \mathrm{s}^{-1}, 92 \mathrm{~mol} \cdot \mathrm{H}_{2} \mathrm{O} \mathrm{m} \mathrm{m}^{-2} \cdot \mathrm{s}^{-1}$, and $6.7 \mu \mathrm{mol} \mathrm{CO}_{2} \mathrm{mmol} \cdot \mathrm{H}_{2} \mathrm{O}^{-1}$, respectively. With the increase in soil Cd content, $P_{n}, G_{s}$, and $W U E$ in leaves decreased significantly. The values of $P_{n}, G_{s}$, and $W U E$ in $\mathrm{Cd} 10$, $\mathrm{Cd} 20, \mathrm{Cd} 50, \mathrm{Cd} 70$, and $\mathrm{Cd} 100$ were decreased from 10.7 to $0.7 \mu \mathrm{mol} \cdot \mathrm{CO}_{2} \mathrm{~m}^{-2} \cdot \mathrm{s}^{-1}, 71.0$ to $35.3 \mathrm{~mol} \cdot \mathrm{H}_{2} \mathrm{O} \mathrm{m} \mathrm{m}^{-2} \cdot \mathrm{s}^{-1}$, and 4.9 to $0.5 \mu \mathrm{mol} \cdot \mathrm{CO}_{2} \mathrm{mmol} \cdot \mathrm{H}_{2} \mathrm{O}^{-1}$, respectively. The intercellular $\mathrm{CO}_{2}$ concentration $\left(C_{i}\right.$, Figure $\left.3 \mathrm{C}\right)$ in leaves showed the opposite trend as $P_{n}, G_{s}$, and WUE. $C_{i}$ in $\mathrm{Cd} 0$ and Cd10 had the lowest values: 118.3 and $126.3 \mu \mathrm{mol} \cdot \mathrm{mol}^{-1}$, respectively. With the increase of soil $\mathrm{Cd}$ content, $C_{i}$ in the $\mathrm{Cd} 20, \mathrm{Cd} 50, \mathrm{Cd} 70$, and $\mathrm{Cd} 100$ treatments ranged from 191.0 to $254.3 \mu \mathrm{mol} \cdot \mathrm{mol}^{-1}$. However, based on the one-way ANOVA, $C_{i}$ in high soil $\mathrm{Cd}$ content $(\mathrm{Cd} 50, \mathrm{Cd} 70$, and Cd100) plants showed no significant differences $(p>0.05$, Figure 3C). The leaf transpiration rate $\left(T_{r}\right.$, Figure $\left.3 \mathrm{D}\right)$ in Cd0 plants was $2.0 \mathrm{mmol} \cdot \mathrm{m}^{-1} \cdot \mathrm{s}^{-1}$. Although compared to $\mathrm{Cd} 0, C_{i}$ in $\mathrm{Cd} 10, \mathrm{Cd} 20$, and $\mathrm{Cd} 50$ plants increased 0.22 , 0.17 , and $0.07 \mathrm{mmol} \cdot \mathrm{m}^{-1} \cdot \mathrm{s}^{-1}$, respectively, there were no remarkable differences between them. With the increase in soil Cd content, $C_{i}$ in $\mathrm{Cd} 70$ and $\mathrm{Cd} 100$ plants showed a significant decrease, and the lowest value was $1.3 \mathrm{mmol} \cdot \mathrm{m}^{-1} \cdot \mathrm{s}^{-1}$ in Cd100 plants.

\section{Leaf Photosynthetic $\mathrm{CO}_{2}$ Response Parameters}

The values for the maximum rate of Rubisco carboxylation $\left(V_{\text {cmax }}\right)$, the maximum rate of RuBP regeneration $\left(J_{\max }\right)$, and the triose phosphate utilization (TPU) fitted from A/Ci curves are shown in Figures $\mathbf{4 A - C}$. The changes in $V_{c \max }, J_{\max }$, and 


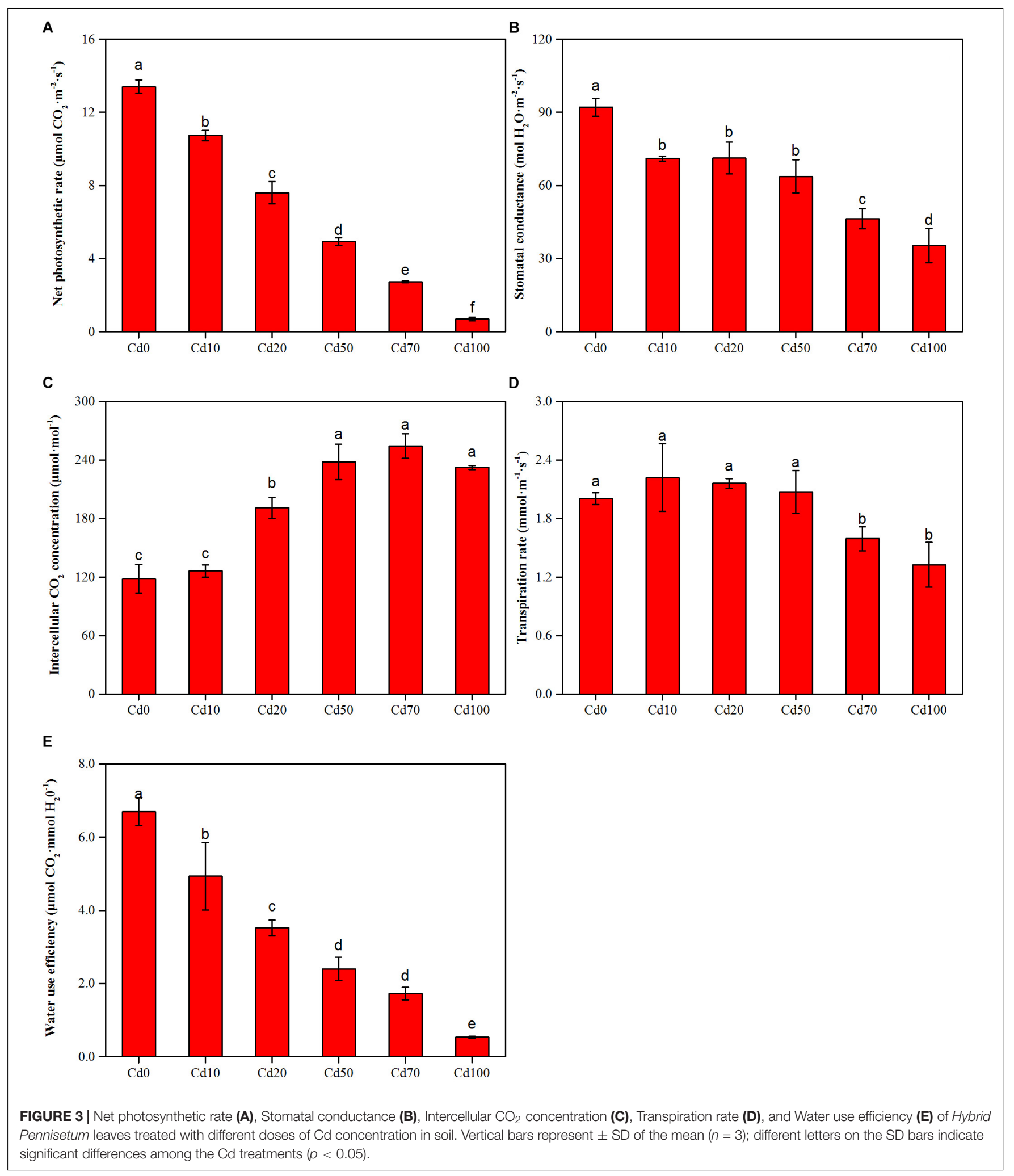

TPU showed similar trends, decreasing with the enhancement of soil Cd content, and the highest values of $V_{c \max }, J_{\max }$, and TPU were found in Cd0 plants $\left(113.5,138.9\right.$, and $8.2 \mu \mathrm{mol} \cdot \mathrm{m}^{-2} \cdot \mathrm{s}^{-1}$, respectively). Compared to Cd0 plants, $V_{c \max }, J_{\max }$, and TPU in $\mathrm{Cd} 10, \mathrm{Cd} 20, \mathrm{Cd} 50, \mathrm{Cd} 70$, and $\mathrm{Cd} 100$ plants decreased by $10.8-52.1,15.1-64.6$, and $2.4-5.7 \mu \mathrm{mol} \cdot \mathrm{m}^{-2} \cdot \mathrm{s}^{-1}$, respectively. 


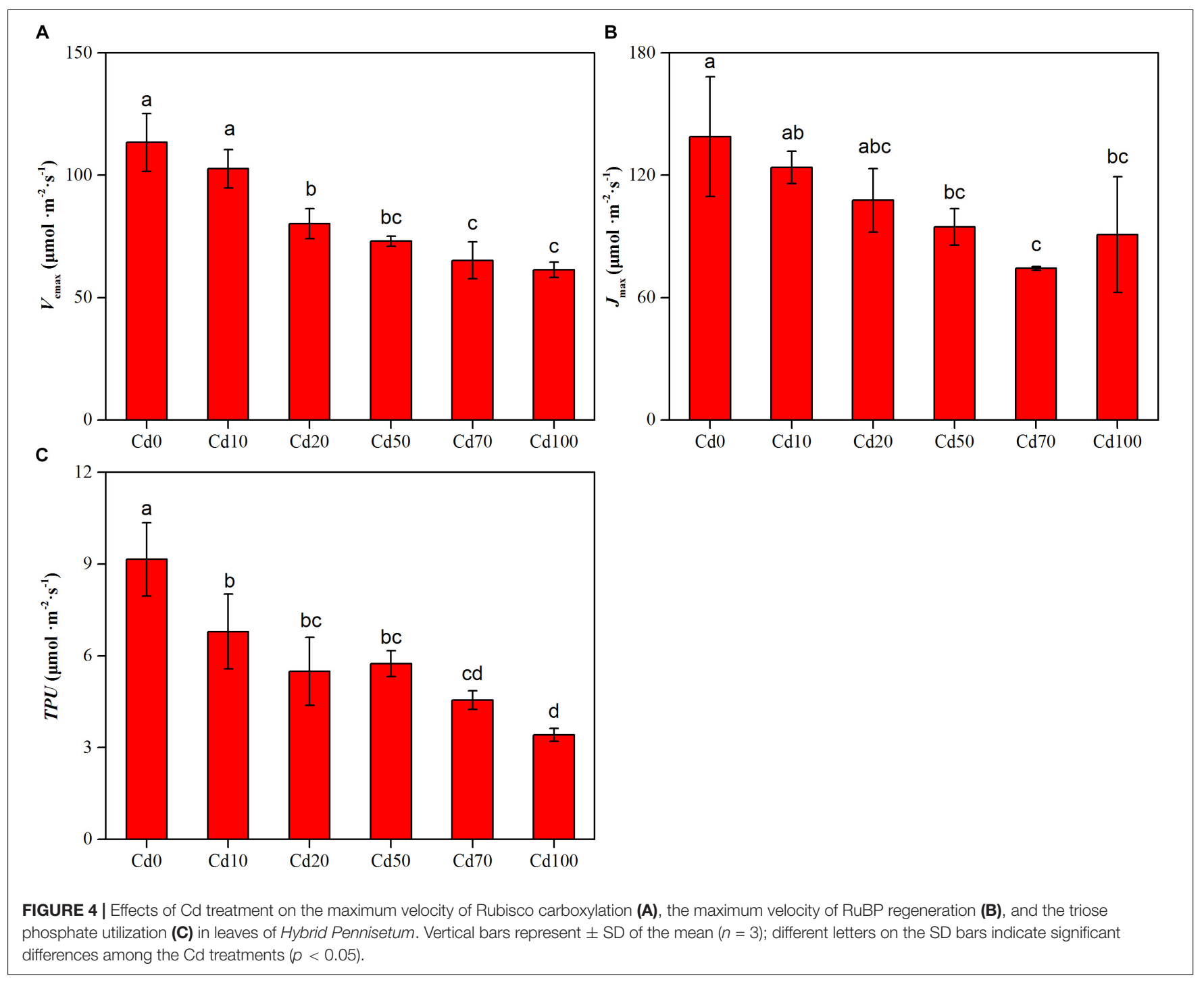

\section{Light Response Curves}

The light response curves of Hybrid Pennisetum in various soil Cd treatments are illustrated in Figure 5. As shown in the light response curves, the response of $P_{n}$ to the light intensity is significantly different during different soil $\mathrm{Cd}$ treatments. The $P_{n}$ in leaves decreased with increasing $\mathrm{Cd}$, and the differences between treatments were more obvious with increasing irradiance. When the level of PAR was higher than that of $L C P$, at the same PAR, the levels of $P_{n}$ were $\mathrm{Cd} 0>\operatorname{Cd} 10>\mathrm{Cd} 20>\mathrm{Cd} 50>\mathrm{Cd} 70>\mathrm{Cd} 100$. According to the simulated analysis of the light response curves (Table 1), $A_{\max }, R_{\text {day }}, A Q Y, L C P$, and LSP in the leaves of Hybrid Pennisetum under Cd0 treatment were $20.7 \mu \mathrm{mol} \cdot \mathrm{CO}_{2} \mathrm{~m}^{-2} \cdot \mathrm{s}^{-1}$, $3.7 \mu \mathrm{mol} \cdot \mathrm{m}^{-2} \cdot \mathrm{s}^{-1}, 0.064 \mathrm{~mol} \cdot \mathrm{mol}^{-1}, 64.6 \mu \mathrm{mol} \cdot \mathrm{m}^{-2} \cdot \mathrm{s}^{-1}$, and $473.7 \mu \mathrm{mol} \cdot \mathrm{m}^{-2} \cdot \mathrm{s}^{-1}$, respectively. When plants suffered soil Cd stress, $A_{\max }, R_{\text {day }}, A Q Y$, and $L S P$ in the leaves of Hybrid Pennisetum decreased with the increase in soil $\mathrm{Cd}$, but $L C P$ in leaves that grew with high soil $\mathrm{Cd}$ was higher than the $L C P$ of leaves that grew with low soil Cd. Compared with the Cd0 treatment, $A_{\max }, R_{d a y}$, and $A Q Y$ in Cd10, Cd20, Cd50, Cd70, and Cd100 leaves decreased by 30.0-81.6, 5.4-35.1, and 29.7-62.5\%, respectively, whereas $L C P$ increased by $38.1-130.0 \%$. Although compared to Cd0, the value of $L S P$ increased by $17.7 \mu \mathrm{mol} \cdot \mathrm{m}^{-2} \cdot \mathrm{s}^{-1}$ in Cd10 leaves and decreased by $4.8 \mu \mathrm{mol} \cdot \mathrm{m}^{-2} \cdot \mathrm{s}^{-1}$ in $\mathrm{Cd} 20$ leaves, there were no significant differences among those three treatments $(p<0.05)$. When the soil Cd content reached $50 \mathrm{mg} \mathrm{kg}^{-1}$, LSP showed a remarkable decrease and had the lowest value $\left(409 \mu \mathrm{mol} \cdot \mathrm{m}^{-2} \cdot \mathrm{s}^{-1}\right)$ in the leaves of the Cd100 treatment.

\section{Chlorophyll a Fluorescence Transient Analysis}

Chlorophyll $a$ fluorescence induction kinetics was measured in order to evaluate the inhibitory effects of $\mathrm{Cd}$ on photochemical efficiency of PSII in Hybrid Pennisetum plants (Figure 6). The $\mathrm{Chl} a$ induction curves (O-J-I-P) obtained from different Cd treatments revealed that $\mathrm{Cd}$ stress caused a prominent change in the shape of fluorescence induction curve compared to 


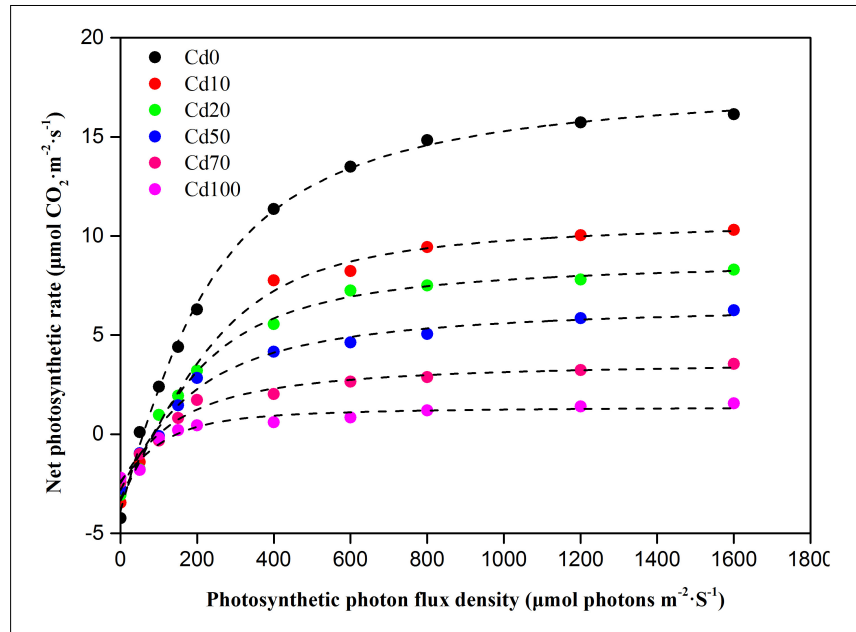

FIGURE 5 | Photosynthetic light response curves in leaves of Hybrid Pennisetum under different soil Cd stress conditions.

control. At the O-J phase, a faster fluorescence increase was found in Cd-treated samples. With the reaction time go on, the curves from the I to $\mathrm{P}$ phase showed a significant decreased under Cd treatment.

A leaf model of phenomenological energy fluxes (per cross-section) was used in the study to present the alteration of PSII energy fluxes in response to Cd stress (Figure 7). In the dynamic model, the energy fluxes such as ABS/CSm, TRo/CSm, ETo/CSm, and DIo/CSm, which were expressed by the width of corresponding arrows, indicate the efficiency of light absorption, trapping and electron transport, and dissipation per cross-section of PS II in different Cd treatments. In the present study, there was no significant difference in energy absorbed per excited cross-section (ABS/CSm), trapped energy flux per $\mathrm{CS}$ (TRO/CSm), and non-photochemical quenching (DIO/CSm) under all Cd treatments. In contrast, the reoxidation of reduced QA via electron transport over a cross-section of active and inactive RCs (ETo/CSm, indicated by a significantly smaller blue arrow) was reduced significantly in Hybrid Pennisetum leaves under Cd stress and gradually decreased with increasing soil $\mathrm{Cd}$ content. Furthermore, the decreased density of the active RCs (indicated as open circles) and the increased density of the inactive RCs (expressed by open closed circles) in the PS II cross-section under Cd stress conditions suggest that electron transport was inhibited because $18-23 \%$ of active RCs were converted into inactive RCs under Cd stress conditions.

\section{DISCUSSION}

Phytoextraction is an important technique that has been widely used to remediate heavy metal contaminated soils by using accumulators to extract contaminants from soil into plants. An ideal phytoextraction plant should have a high metal bioaccumulation factor and a high metal tolerance (Zhao et al., 2003). In our study, there was significant Cd accumulation in the leaves of Hybrid Pennisetum, and the leaf Cd concentration exhibited a remarkable increase with the strength of soil $\mathrm{Cd}$ stress. The results indicated that Hybrid Pennisetum has a high ability to uptake $\mathrm{Cd}$ metal and quickly transfer $\mathrm{Cd}^{2+}$ from roots to leaves. According to the study of Lux et al. (2011), leaf $\mathrm{Cd}$ concentrations exceeding $5-10 \mu \mathrm{g} \mathrm{g}^{-1}$ are toxic to most plants. After 3 months of Cd treatments on Hybrid Pennisetum, the leaf $\mathrm{Cd}$ concentrations reached $63.5 \mu \mathrm{g} \mathrm{g}^{-1}$ at $\mathrm{Cd} 50,76.4 \mu \mathrm{g} \mathrm{g}^{-1}$ at $\mathrm{Cd} 70$, and $86.4 \mu \mathrm{g} \mathrm{g}^{-1}$ at $\mathrm{Cd} 100$ treatment. Although photosynthesis was extremely suppressed under high Cd treatments, Hybrid Pennisetum still had a low carbon assimilation ability $\left(P_{n}\right.$ in $\mathrm{Cd} 50, \mathrm{Cd} 70$, and $\mathrm{Cd} 100$ were $4.9,2.7$, and $0.7 \mu \mathrm{mol} \mathrm{CO} \mathrm{m}^{-2} \cdot \mathrm{s}^{-1}$, respectively).

Chloroplasts are pigments that play an important role in light energy absorption, transmission, and conversion to chemical energy during photosynthesis. The reduction of chlorophyll content and the inhibition of chlorophyll synthesis were proved to be the primary causes of diminished photosynthetic activity (Yasemin et al., 2008). In the present study, the progressive decreased photosynthetic activity in Hybrid Pennisetum was partially attributable to the remarkably reduced chloroplast contents due to exposure to Cd (Figure 2). Similar results were observed in a previous study in which chlorophyll and carotenoid concentrations in leaves decreased as a result of Cd stress ( $\mathrm{Su}$ and Wang, 2004; Pagliano et al., 2006; Ahammed et al., 2012; $\mathrm{Xu}$ et al., 2014; Per et al., 2016). The chloroplast reduction could be explained by $\mathrm{Cd}$ replacing the magnesium atom within chlorophyll to form a chlorophyll-Cd complex. This replacement results in damage to the photosynthetic apparatus (Siedlecka et al., 1998) and inhibits the production of chlorophyll by

TABLE 1 | Cd stress effect on light-saturated photosynthesis, apparent quantum yield, light compensation point, light saturation point, and dark respiration in leaves of Hybrid Pennisetum.

\begin{tabular}{|c|c|c|c|c|c|}
\hline Treatment & $\begin{array}{c}A_{\max } \\
\left(\mu \mathrm{mol} \cdot \mathrm{CO}_{2} \mathrm{~m}^{-2} \cdot \mathrm{s}^{-1}\right)\end{array}$ & $\begin{array}{c}R_{\text {day }} \\
\left(\mu \mathrm{mol} \cdot \mathrm{m}^{-2} \cdot \mathrm{s}^{-1}\right)\end{array}$ & $\begin{array}{c}A Q Y \\
\left(\mathrm{~mol} \cdot \mathrm{mol}^{-1}\right)\end{array}$ & $\begin{array}{c}L C P \\
\left(\mu \mathrm{mol} \cdot \mathrm{m}^{-2} \cdot \mathrm{s}^{-1}\right)\end{array}$ & $\begin{array}{c}L S P \\
\left(\mu \mathrm{mol} \cdot \mathrm{m}^{-2} \cdot \mathrm{s}^{-1}\right)\end{array}$ \\
\hline $\mathrm{CdO}$ & $20.7 \pm 0.3 a$ & $3.7 \pm 0.2 \mathrm{a}$ & $0.064 \pm 0.004 \mathrm{a}$ & $64.6 \pm 1.7 \mathrm{e}$ & $473.7 \pm 8.2 \mathrm{a}$ \\
\hline Cd10 & $14.5 \pm 0.2 b$ & $3.5 \pm 0.1 \mathrm{ab}$ & $0.045 \pm 0.002 b$ & $89.2 \pm 1.6 \mathrm{~d}$ & $491.4 \pm 19.3 \mathrm{a}$ \\
\hline Cd20 & $12.2 \pm 0.3 c$ & $3.2 \pm 0.2 b$ & $0.042 \pm 0.002 \mathrm{bc}$ & $92.2 \pm 0.8 d$ & $468.9 \pm 36.4 \mathrm{ab}$ \\
\hline Cd50 & $9.3 \pm 0.2 \mathrm{~d}$ & $2.7 \pm 0.1 \mathrm{c}$ & $0.037 \pm 0.002 \mathrm{~cd}$ & $96.5 \pm 2.0 \mathrm{c}$ & $437.9 \pm 10.5 b c$ \\
\hline $\mathrm{Cd} 70$ & $6.2 \pm 0.3 \mathrm{e}$ & $2.5 \pm 0.3 c$ & $0.034 \pm 0.007 \mathrm{~d}$ & $111.7 \pm 2.7 b$ & $419.0 \pm 11.6 \mathrm{c}$ \\
\hline Cd100 & $3.8 \pm 0.1 f$ & $2.4 \pm 0.01 c$ & $0.024 \pm 0.003 \mathrm{e}$ & $148.6 \pm 2.1 \mathrm{a}$ & $409.4 \pm 3.4 c$ \\
\hline
\end{tabular}

Values are the mean of three replicates. Different letters indicate that values are significantly different from each other at $p \leq 0.05$. 


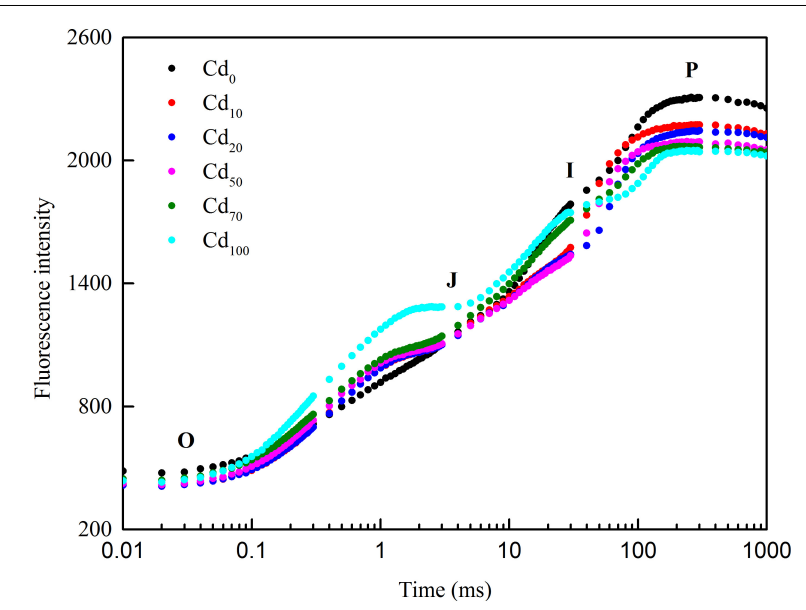

FIGURE 6 | The fluorescence intensity of the original fluorescence kinetic curve of Hybrid Pennisetum leaves under different Cd treatments.

obstructing the formation of the protochlorophyllide reductase ternary complex and the synthesis of 5-aminolaevulinic acid (Huang et al., 1997) and by reducing chlorophyll synthesis (Gonçalves et al., 2009) or enhancing enzymatic degradation (Somashekaraiah et al., 1992).

Cadmium toxicity caused a notable reduction in the photosynthetic rate in different plant species (Alexander et al., 2008). However, in other studies, no direct $\mathrm{Cd}$ effects on the photosystem were found in either Brassica juncea
(Haag et al., 1999) or Arabidopsis thaliana (Laetitia et al., 2010) plants. These contrasting results could be explained by a threshold of phytotoxic concentration of Cd toxicity in plants that depends on plant species, ecotypes, cultivars, and even plant tissues ( $\mathrm{He}$ et al., 2015). In our study, Cd caused a significant reduction in $P_{n}$ (Figure 3A), indicating that plant carbon assimilation ability was suppressed due to $\mathrm{Cd}$ toxicity. Accompanied by the significant reduction in $P_{n}$, lower $G_{s}$ (Figure 3B) and higher $C_{i}$ (Figure 3C) were simultaneously observed in Hybrid Pennisetum leaves. The results indicated that the decrease in $P_{n}$ did not result from a low $G_{s}$ or low $\mathrm{CO}_{2}$ concentration in chloroplasts because the $C_{i}$ levels were even higher in leaves of those plants treated with $\mathrm{Cd}$ than in the control, indicating that $\mathrm{Cd}$ reduced $P_{n}$ by reducing $\mathrm{CO}_{2}$ fixation by Rubisco (Wahid et al., 2010). Therefore, the inhibition of photosynthetic processes by Cd in Hybrid Pennisetum was due to non-stomatal restriction but not stomatal limitation. These findings agree with the effect of $\mathrm{Cd}$ shown on $\mathrm{CO}_{2}$ fixation in cucumber (Feng et al., 2010), lettuce (Monteiro et al., 2009), and Ceratopteris pteridoides (Deng et al., 2014). Although the stomata were closed by Cd stress, the $T_{r}$ of Hybrid Pennisetum in the $\mathrm{Cd} 10, \mathrm{Cd} 20$, and $\mathrm{Cd} 50$ treatments maintained a stable value (Figure 3D), indicating that the transpiration of Hybrid Pennisetum was not affected by the addition of $50 \mathrm{mg} \mathrm{kg}^{-1} \mathrm{Cd}$ to the soil. On the contrary, $T_{r}$ in Cd70 and Cd100 treatment decreased significantly due to the remarkable stomata closure. $\mathrm{Cd}$ stress also produced disturbances in water balance, and a noticeable reduction of WUE was observed in all Cd treatments (Figure 3E). This could be explained by the inhibition of
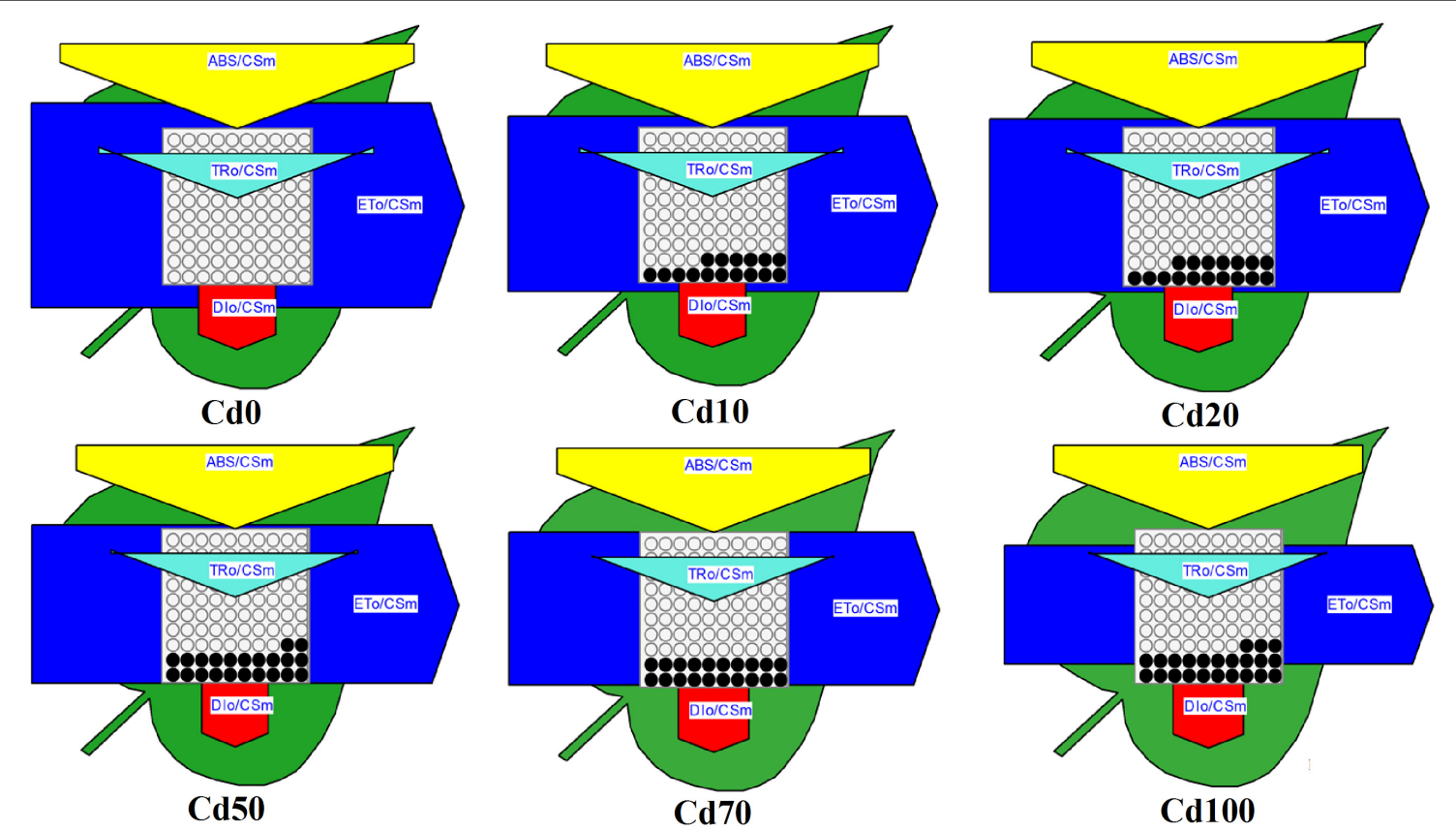

FIGURE 7 | Energy pipeline leaf model of phenomenological fluxes (per cross-section, CS) in last fully expanded leaves as affected by Cd stress. Data are means \pm standard errors $(n=3)$. Each relative value is drawn by the width of the corresponding arrow, standing for a parameter. Empty and full black circles indicate, respectively, the percentage of active (QA reducing) and non-active (non-QA reducing) reaction centers of PS II. TRO/CSm - trapped energy flux per CS; ETO/CSm - electron transport flux per CS; ABS/CSm - absorption flux per CS; DIO/CSm - non-photochemical quenching per CS. 
absorption and translocation of water, as previously observed by Barceló and Poschenrieder (1990) and Singh et al. (2008). Figure 8 exhibits the non-stomatal limitation in regulating the photosynthetic performance of Hybrid Pennisetum under Cd stress conditions.

The non-stomatal limitation of photosynthesis could be expressed by the change in photosynthetic capacity. The $V_{c \max }$ at low $\mathrm{CO}_{2}$ concentrations and $J_{\text {max }}$ at high $\mathrm{CO}_{2}$ concentrations are often used to reflect the photosynthetic capacity of plants in response to environmental stress (Farquhar et al., 1980; Sharkey et al., 2007; Song et al., 2016). In our study, Cd stress caused a decrease in $V_{c m a x}$ and $J_{\max }$ of Hybrid Pennisetum (Figure 4). The decline in the $V_{\text {cmax }}$ might be due to the reduced amount of active Rubisco (Peña-Rojas et al., 2004), and the reduction in the $J_{\max }$ might be due to the limited activity of photosynthetic enzyme (such as sedoheptulose-1,7bisphosphatase and fructose-1,6-bisphosphatase) and the insufficient supply of NADPH or ATP (Lawlor and Cornic, 2010). The relationship between $V_{c \max }$ and $J_{\max }$ represents resource allocation between the two photosynthetic cycleselectron transport and the Calvin-Benson cycle (Walker et al., 2015). In this study, $J_{\max }$ was strongly related to $V_{c \max }$, and neither leaf nitrogen, phosphorus, nor specific leaf area had a substantial impact on the relationship. Similar results were supported by the analysis of empirical data from 109 species (Wullschleger, 1993). As shown in Figure 9, although the changes in the two parameters were different among the various
Cd treatments, there was a significant positive linear relationship between $J_{\max }$ and $V_{\text {cmax }}(p<0.01)$. The result suggested the viewpoint of (Walker et al., 2015), that tight coupling of $J_{\max }$ with $V_{\text {cmax }}$ is a fundamental feature of plant photosynthetic trait relationships regardless of whether Hybrid Pennisetum suffered environmental stress. Triose phosphate utilization occurs when the chloroplast reactions have a higher rate than the capacity of the leaf to use the products of the chloroplasts (Sharkey et al., 2007). TPU is the rate of use of triose phosphates and it has been proposed to at least provide an indication of the feedback between growth and $\mathrm{CO}_{2}$ assimilation (Wullschleger, 1993). The drop in TPU in the Cd-treated plants (Figure 4) could be related to the decrease in the sink strength of the roots and leaves (Long and Bernacchi, 2003; Sharkey et al., 2007).

The light response curve has been widely used for reflecting the photochemical efficiency of plant photosynthesis in response to environmental factors such as drought (Song et al., 2016), elevated $\mathrm{CO}_{2}$ concentration (Herrick and Thomas, 1999), heat (Lewis et al., 1999), salt (Li and Ong, 1998), and metal stress (Zhang et al., 2014). The parameter $A_{\text {max }}$, which reflects the maximum photosynthetic capacity of the leaf (Zhou et al., 2010), is the maximum absolute value of photosynthesis under optimal environmental conditions (Tartachnyk and Blanke, 2004). In our study, $A_{\max }$ was significantly reduced by $\mathrm{Cd}$ stress. As shown in Table 1, compared to Cd0, $A_{\max }$ decreased by $6.2 \mu \mathrm{mol} \cdot \mathrm{CO}_{2} \mathrm{~m}^{-2} \cdot \mathrm{s}^{-1}$ even at a low $\mathrm{Cd}$ concentration (10 $\mathrm{mg} \mathrm{kg}^{-1}$ in $\mathrm{Cd} 10$ ). AQY could be used to reflect the plant's

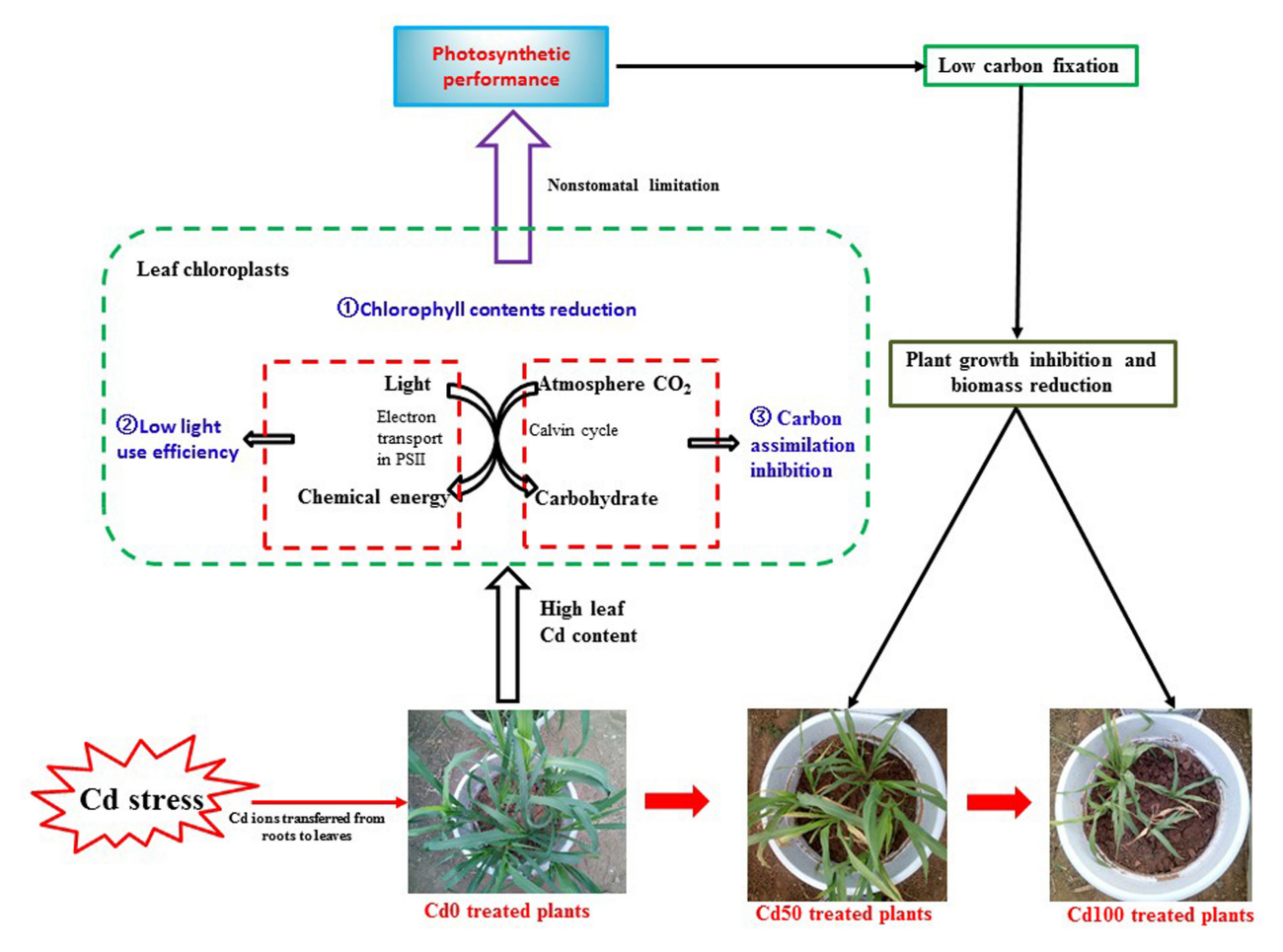

FIGURE 8 | Schematic representation of the non-stomatal limitation in regulating the photosynthetic performance of Hybrid Pennisetum under Cd stress conditions. The figure shows that the decrease in leaf chlorophyll content, reduction of the ability to use light, and restrictions on carbon assimilation caused by high Cd content in leaves limit the capacity of Hybrid Pennisetum in carbon fixation. 


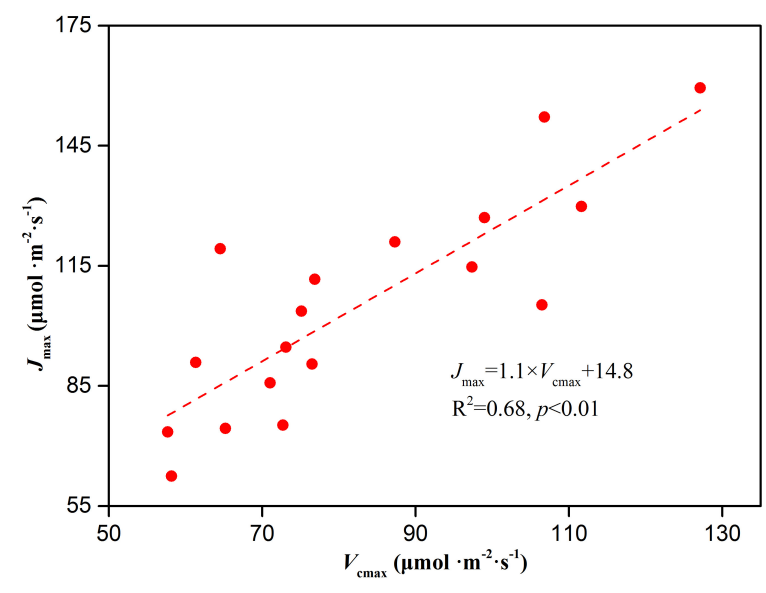

FIGURE 9 | The relationship between $J_{\max }$ and $V_{\text {cmax }}$ in leaves of Hybrid Pennisetum.

ability in absorbing, converting, and using light energy at low light intensities, and high $A Q Y$ indicates that plants have a high light energy transfer efficiency (Marshall and Biscoe, 1980). In the present study, the change in $A Q Y$ showed a similar trend as $A_{\max }$ and decreased with increasing $\mathrm{Cd}$ concentration. This decline in the light use efficiency of Hybrid Pennisetum shows plants' self-photoprotection mechanism in avoiding damage (Zhu et al., 2004). Under light saturation conditions, Cd stress inhibited the photochemical reactions, resulting the excitation energy could not be used in photochemical reactions totally. To protect the photosynthetic apparatus like chloroplast and cell membrane from being damaged by the excess excitation energy, the plant activates the self-photoprotection mechanism by dissipating the excess excitation energy as harmless heat through the xanthophyll cycle (Omasa and Takayama, 2003). With more heat dissipation, the light use efficiency was lower and the decrease in the photosynthetic rate was higher (Song et al., 2016).

Light saturation point and LCP reflect the plant ability in using high and low light intensities. They are very useful primary indicators for measuring the relationship between light use and photosynthesis (Zhou et al., 2010). When the environmental conditions are not suitable, plants typically decrease the LSP or increase the LCP to ensure the normal operation of photosynthesis. In our study, compared to Cd0, LSP decreased and LCP increased with increasing soil Cd concentration (Figure 5 and Table 1), suggesting that soil Cd stress decreased the light use efficiency both at high light levels and at low light levels. The decreased light use efficiency at LSP showed the inhibition of $\mathrm{CO}_{2}$ assimilation ability in Hybrid Pennisetum. Furthermore, LCP is the light value at which the rate of $\mathrm{CO}_{2}$ release by respiration and photorespiration is equal to the rate of $\mathrm{CO}_{2}$ fixation by photosynthesis. High $L C P$ reflects plants suffers higher respiration and lower Rubisco carboxylase activity or higher Rubisco oxygenase activity (Nunes et al., 2010). The obvious increase in LCP in Cd-treated plants observed in the present study implies that $\mathrm{Cd}$ could inhibit both photosynthesis and organic compounds accumulation in
Hybrid Pennisetum (Zhang et al., 2014). $R_{d}$, which is the index of the plant respiration rate in the dark, provides the power for a plant's metabolic activity (Arnold et al., 2002). The decrease of $R_{d}$ under various Cd stress conditions, as shown in Table 1, reflects the reduction in the need for energy and intermediate metabolites, resulting in an extremely inhibited plant physiological activity (Atkin and Macherel, 2009). The Cd stress caused by the accumulation of $\mathrm{Cd}$ in leaves was the first and main reason for the reduction in both $A_{\max }$ and $R_{d}$. We hypothesized that there was a significant relationship between $A_{\max }$ and $R_{d}$ and leaf Cd concentration $\left(L_{c d}\right)$. To test this hypothesis, linear curves were fitted to determine the relation between $A_{\max }$ and $L_{c d}$ as well as the relation between $R_{d a y}$ and $L_{c d}$ in Figure 10. The fitted linear curves showed that $A_{\max }$ and $R_{\text {day }}$ had a noticeable negative relationship with $L_{c d}(p<0.01)$, indicating that the maximum photosynthetic capacity and respiration rate of Hybrid Pennisetum were significantly suppressed with the increase of $\mathrm{Cd}$ concentration in Hybrid Pennisetum leaves. It is important to note that we used $A_{\max }$ but not $P_{n}$ to determine the relationship with $L_{c d}$. The reason is that $P_{n}$ as an instantaneous measure parameter is very affected by the change in PPFD at different measurement times. Relatively, $A_{\max }$ was more stable than $P_{n}$ because it was measured under optimal environmental conditions.

Chl fluorescence has a close relationship with plant photosynthesis, and Chl fluorescence analysis has been proven to be a useful tool in monitoring the influence of various stress conditions, such as salt (Mehta et al., 2010; Sun et al., 2016), high temperature (Mathur et al., 2015), pH (Tongra et al., 2011; Long et al., 2017), drought (Oukarroum et al., 2007), fluoranthene (Rupal and Anjana, 2013), photooxidation (Jing et al., 2017), and heavy metals (Hendrik et al., 2010; Goussi et al., 2018), on the photosynthetic activity of plants or microalgae/cyanobacteria. Although Chl fluorescence emissions only account for $2-5 \%$ of the energy that is not used in photosynthesis (Zhao et al., 2018), it can supply extensive information related to the components,

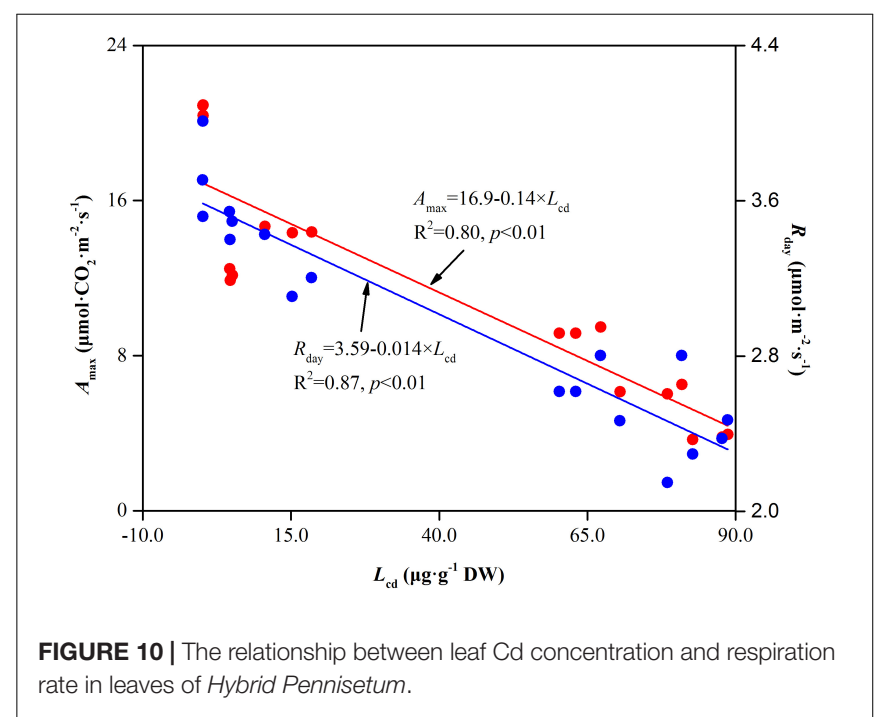


structure, and function of plant photosynthetic performance (Strasser et al., 2004). Changes in Chl fluorescence indicate a decline in the ability of plants to cope with excess light intensity both in protective regulatory mechanisms and in the regulation of PSII (Logan, 2007). Therefore, any small change in Chl fluorescence in plants can be used to identify the response of plants to environmental stress. PSII of photosynthesis has been proven to be the primary target of Cd toxicity (Alexander et al., 2008; Popova et al., 2009). To characterize the PSII activities in Cd-treated plants, the OJIP transients that reflect the successive reduction in the electron pools (Pheo, QA and QB) of PSII (Strasser et al., 2004) were used in our study. The OJ phase in the OJIP transients is strongly light dependent (Neubauer and Schreiber, 1987; Schansker et al., 2015) and contains information on antenna size and connectivity between PSII reaction centers. The $\mathrm{J}$ to $\mathrm{P}$ rise in the OJIP transients is called the thermal phase and reflects a reduction in the rest of the electron transport chain (Schansker et al., 2005). As shown in Figure 6, a faster fluorescence increase in samples treated with different Cd stress was found at the $\mathrm{OJ}$ phase, indicating that the reoxidation of $\mathrm{QA}^{-}$ is inhibited and that there is a larger accumulation of $\mathrm{QA}^{-}$due to the curtailment efficiency of electron transport beyond QA (Strasser and Govindjee, 1992; Strauss et al., 2006; Chen et al., 2011; Kalaji et al., 2017). With the increase in reaction times, the curves from the I phase to the P phase under Cd treatment decreased, indicating a slowdown in electron donation from the PSII donor side (Oukarroum et al., 2015). The different shapes of the fluorescence induction curves under different $\mathrm{Cd}$ treatments compared to the $\mathrm{Cd} 0$ treatment indicated that $\mathrm{Cd}$ toxicity not only inhibited the light use efficiency but also the ability to avoid photodamage.

The dynamic energy pipeline leaf model of the photosynthetic apparatus has been shown to be a direct and visual way to present the alteration of PSII energy fluxes (Li et al., 2014; Sun et al., 2016). In the present study, except for ETo/CSm, the other parameters, such as ABS/CSm, TR0/CSm, and DI0/CSm, showed no significant reduction during all Cd treatments compared with $\mathrm{Cd} 0$ plants (Figure 7). The unchanging ABS/CSm suggested that the energy trapped per excited CS was not suppressed by Cd. Electron transport (ETo/CSm) decreased with Cd treatment, indicating the inactivation of reaction center complexes. The ratio TR0/CSm and DI0/CSm was not significantly affected by $\mathrm{Cd}$, indicating that the trapped light in the reaction centers was not affected significantly and that the excess energy was not dissipated in the form of heat but was utilized in some other form. In addition, the decreased ETo/CSm and relatively stable

\section{REFERENCES}

Ahammed, G. J., Yuan, H. L., Ogweno, J. O., Zhou, Y. H., Xia, X. J., Mao, W. H., et al. (2012). Brassinosteroid alleviates phenanthrene and pyrene phytotoxicity by increasing detoxification activity and photosynthesis in tomato. Chemosphere 86, 546-555. doi: 10.1016/j.chemosphere.2011.10.038

Alexander, K., Rusina, Y., Tibor, J., Gabriella, S., and Losanka, P. (2008). Treatment with salicylic acid decreases the effect of cadmium on photosynthesis in maize plants. J. Plant Physiol. 165, 920-931. doi: 10.1016/j.jplph.2006. 11.014
DIO/CSm contributed to the imbalance between light energy absorbed by photosystems and energy consumed by metabolic sinks in the plant.

\section{CONCLUSION}

In this study, we concluded that the high $\mathrm{Cd}$ concentration in the leaves of Hybrid Pennisetum caused acute Cd toxicity by impairing photosynthetic performance after 3 months of soil Cd treatments. According to the changes in gas exchange parameters under Cd stress conditions, non-stomatal limitation, rather than stomatal limitation, regulates the photosynthetic processes of Hybrid Pennisetum. The mechanism by which Cd stress affected photosynthesis in Hybrid Pennisetum was through decreasing the leaf chlorophyll content, inhibiting Rubisco activity, RuBP regeneration, and triose phosphate utilization, reducing both light use and energy-providing ability, and preventing electron transport in PSII. The inhibition of photosynthetic processes caused a significant decrease in photosynthetic capacity.

\section{DATA AVAILABILITY}

All datasets generated for this study are included in the manuscript.

\section{AUTHOR CONTRIBUTIONS}

WC and HJ conceived the experiment. XY, YH, XL, and XS conducted the experiment. XS analyzed the results and wrote the manuscript. All authors reviewed and approved the manuscript.

\section{FUNDING}

This work was supported by the Shandong Provincial Agricultural Seed-Breeding Improvement Program (Grant No. 2017LZN009).

\section{ACKNOWLEDGMENTS}

The authors thank Man Chen and Derui Wang for her help during the experiment.

Arnold, S. V., Sabala, I., Bozhkov, P., Dyachok, J., and Filonova, L. (2002) Developmental pathways of somatic embryogenesis. Plant Cell Tissue Organ Cult. 69, 233-249. doi: 10.1023/a:1015673200621

Atkin, O. K., and Macherel, D. (2009). The crucial role of plant mitochondria in orchestrating drought tolerance. Ann. Bot. 103, 581-597. doi: 10.1093/aob/ mcn094

Baek, K. H., Kim, H. S., Oh, H. M., Yoon, B. D., Kim, J., and Lee, I. S. (2004). Effects of crude oil, oil components, and bioremediation on plant growth. J. Environ. Sci. Health Part A 39, 2465-2472. doi: 10.1081/ESE-2000 26309 
Barceló, J., and Poschenrieder, C. (1990). Plant water relations as affected by heavy metal stress: a review. J. Plant Nutr. 13, 1-37. doi: 10.1080/0190416900936 4057

Brestic, M., Zivcak, M., Kunderlikova, K., Sytar, O., Shao, H., Kalaji, H. M., et al. (2015). Low PSI content limits the photoprotection of PSI and PSII in early growth stages of chlorophyll b-deficient wheat mutant lines. Photosynthesis Research 125, 151-166. doi: 10.1007/s11120-015-0093-1

Chen, S., Zhou, F., Yin, C., Strasser, R. J., Yang, C., and Sheng, Q. (2011). Application of fast chlorophyll a fluorescence kinetics to probe action target of 3-acetyl-5-isopropyltetramic acid. Environ. Exp. Bot. 71, 269-279. doi: 10.1016/ j.envexpbot.2011.08.005

Clemens, S., Aarts, M. G. M., Thomine, S., and Verbruggen, N. (2013). Plant science: the key to preventing slow cadmium poisoning. Trends Plant Sci. 18, 92-99. doi: 10.1016/j.tplants.2012.08.003

Deng, G., Ming, L. I., Hong, L. I., Yin, L., and Wei, L. I. (2014). Exposure to cadmium causes declines in growth and photosynthesis in the endangered aquatic fern (Ceratopteris pteridoides). Aquat. Bot. 112, 23-32. doi: 10.1016/j. aquabot.2013.07.003

Erdal, S., and Turk, H. (2016). Cysteine-induced upregulation of nitrogen metabolism-related genes and enzyme activities enhance tolerance of maize seedlings to cadmium stress. Environ. Exp. Bot. 132, 92-99. doi: 10.1016/j. envexpbot.2016.08.014

Faller, P., Kienzler, K., and Krieger-Liszkay, A. (2005). Mechanism of $\mathrm{Cd}^{2+}$ toxicity: $\mathrm{Cd}^{2+}$ inhibits photoactivation of Photosystem II by competitive binding to the essential $\mathrm{Ca}^{2+}$ site. Biochim. Biophys. Acta 1706, 158-164. doi: 10.1016/j.bbabio. 2004.10.005

Farquhar, G. D., Von, C. S., and Berry, J. A. (1980). A biochemical model of photosynthetic $\mathrm{CO}_{2}$ assimilation in leaves of C3 species. Planta 149, 78-90. doi: 10.1007/BF00386231

Feng, J., Shi, Q., Wang, X., Wei, M., Yang, F., and Xu, H. (2010). Silicon supplementation ameliorated the inhibition of photosynthesis and nitrate metabolism by cadmium (Cd) toxicity in Cucumis sativus L. Sci. Hortic. 123, 521-530. doi: 10.1016/j.scienta.2009.10.013

Fornazier, R. F. (2002). Changes in antioxidant enzyme activities in soybean under cadmium stress. J. Plant Nutr. 25, 327-342. doi: 10.1081/PLN-100108839

Gallego, S. M., Pena, L. B., Barcia, R. A., Azpilicueta, C. E., Iannone, M. F., Rosales, E. P., et al. (2012). Unravelling cadmium toxicity and tolerance in plants: insight into regulatory mechanisms. Environ. Exp. Bot. 83, 33-46. doi: 10.1016/j.envexpbot.2012.04.006

Ghnaya, T., Nouairi, I., Slama, I., Messedi, D., Grignon, C., Abdelly, C., et al. (2005). Cadmium effects on growth and mineral nutrition of two halophytes: Sesuvium portulacastrum and Mesembryanthemum crystallinum. J. Plant Physiol. 162, 1133-1140. doi: 10.1016/j.jplph.2004.11.011

Ghosh, M., and Singh, S. P. (2005). A comparative study of cadmium phytoextraction by accumulator and weed species. Environ. Pollut. 133, 365-371. doi: 10.1016/j.envpol.2004.05.015

Gonçalves, J. F., Nicoloso, F. T., Becker, A. G., Pereira, L. B., Tabaldi, L. A., Cargnelutti, D., et al. (2009). Photosynthetic pigments content, $\delta$ aminolevulinic acid dehydratase and acid phosphatase activities and mineral nutrients concentration in cadmium-exposed Cucumis sativus L. Biologia 64, 310-318. doi: 10.2478/s11756-009-0034-6

Goussi, R., Manaa, A., Derbali, W., Ghnaya, T., Abdelly, C., and Barbato, R. (2018). Combined effects of $\mathrm{NaCl}$ and $\mathrm{Cd} 2+$ stress on the photosynthetic apparatus of Thellungiella salsuginea. Biochim. Biophys. Acta 1859, 1274-1287. doi: 10.1016/ j.bbabio.2018.10.001

Groppa, M. D., Ianuzzo, M. P., Rosales, E. P., Vázquez, S. C., and Benavides, M. P. (2012). Cadmium modulates NADPH oxidase activity and expression in sunflower leaves. Biol. Plant. 56, 167-171. doi: 10.1007/s10535-012-0036-z

Groppa, M. D., Tomaro, M. L., and Benavides, M. P. (2007). Polyamines and heavy metal stress: the antioxidant behavior of spermine in cadmium- and coppertreated wheat leaves. Biometals 20, 185-195. doi: 10.1007/s10534-006-90 $26-y$

Guidi, L., Degl'Innocenti, E., Remorini, D., Massai, R., and Tattini, M. (2008). Interactions of water stress and solar irradiance on the physiology and biochemistry of Ligustrum vulgare. Tree Physiol. 28, 873-883. doi: 10.1093/ treephys/28.6.873

Haag, K. A., Schafer, H., Heiss, S., Walter, C., and Rausch, T. (1999). Cadmium stress in Brassica juncea causes a decline in transpiration rate and leaf expansion without effect on photosynthesis. J. Exp. Bot. 50, 1827-1835. doi: 10.1093/ jexbot/50.341.1827

He, S., He, Z., Yang, X., Stoffella, P. J., and Baligar, V. C. (2015). Soil biogeochemistry, plant physiology, and phytoremediation of cadmiumcontaminated soils. Adv. Agron. 134, 135-225. doi: 10.1016/bs.agron.2015. 06.005

Hendrik, K., Aravind, P., Barbara, L., Martin, T., and Ivan, S. (2010). Cadmiuminduced inhibition of photosynthesis and long-term acclimation to cadmium stress in the hyperaccumulator Thlaspi caerulescens. New Phytol. 175, 655-674. doi: 10.1111/j.1469-8137.2007.02139.x

Herrick, J. D., and Thomas, R. B. (1999). Effects of $\mathrm{CO}_{2}$ enrichment on the photosynthetic light response of sun and shade leaves of canopy sweetgum (Liquidambar styraciflua) in a forest ecosystem. Tree Physiology 19, 779-786. doi: 10.1093/treephys/19.12.779

Horváth, G., Droppa, M., Oravecz, Á., Raskin, V. I., and Marder, J. B. (1996). Formation of the photosynthetic apparatus during greening of cadmiumpoisoned barley leaves. Planta 199, 238-243. doi: 10.2307/23384301

Huang, X. D., Mcconkey, B. J., Babu, T. S., and Greenberg, B. M. (1997). Mechanisms of photoinduced toxicity of photomodified anthracene to plants: inhibition of photosynthesis in the aquatic higher plant Lemna gibba (duckweed). Environ. Toxicol. Chem. 16, 1707-1715. doi: 10.1002/etc. 5620160819

Jing, M., Lv, C., Xu, M., Hao, P., Wang, Y., Shen, W., et al. (2017). Analysis of chlorophyll a fluorescence and proteomic differences of rice leaves in response to photooxidation. Acta Physiol. Plant. 39:46. doi: 10.1007/s11738-0162342-0

Joshi, M. K., and Mohanty, P. (2004). "Chlorophyll a fluorescence as a probe of heavy metal ion toxicity in plants," in Chlorophyll a Fluorescence. Advances in Photosynthesis and Respiration, Vol. 19, eds G. C. Papageorgiou and Govindjee (Dordrecht: Springer). doi: 10.1007/978-1-4020-3218-9_25

Kalaji, H. M., Račková, L., Paganová, V., Swoczyna, T., Rusinowski, S., and Sitko, K. (2017). Can chlorophyll- a fluorescence parameters be used as bio-indicators to distinguish between drought and salinity stress in Tilia cordata Mill? Environ. Exp. Bot. 152, 149-157. doi: 10.1016/j.envexpbot.2017.11.001

Laetitia, P. B., Nathalie, L., Alain, V., and Cyrille, F. (2010). Heavy metal toxicity: cadmium permeates through calcium channels and disturbs the plant water status. Plant J. 32, 539-548. doi: 10.1046/j.1365-313X.2002.01442.x

Lawlor, D. W., and Cornic, G. (2010). Photosynthetic carbon assimilation and associated metabolism in relation to water deficits in higher plants [Review]. Plant Cell Environ. 25, 275-294. doi: 10.1046/j.0016-8025.2001. 00814.x

Lee, K. C., Cunningham, B. A., Paulsen, G. M., Liang, G. H., and Moore, R. B. (2010). Effects of Cadmium on respiration rate and activities of several enzymes in soybean seedlings. Physiol. Plant. 36, 4-6. doi: 10.1111/j.1399-3054.1976. tb05017.x

Lewis, J. D., Olszyk, D., and Tingey, D. T. (1999). Seasonal patterns of photosynthetic light response in Douglas-fir seedlings subjected to elevated atmospheric $\mathrm{CO}_{2}$ and temperature. Tree Physiol. 19, 243-252. doi: 10.1093/ treephys/19.4-5.243

Li, M. P., and Ong, B. L. (1998). Responses of photosynthesis to $\mathrm{NaCl}$ in gametophytes of Acrostichum aureum. Physiol. Plant. 102, 119-127. doi: 10. 1034/j.1399-3054.1998.1020116.x

Li, Q., Lu, Y., Shi, Y., Wang, T., Ni, K., Xu, L., et al. (2013). Combined effects of cadmium and fluoranthene on germination, growth and photosynthesis of soybean seedlings. J. Environ. Sci. 25, 1936-1946. doi: 10.1016/S1001-0742(12) 60264-2

Li, X., Jian, C., Liu, F., Dai, T., Cao, W., and Dong, J. (2014). Cold priming drives the sub-cellular antioxidant systems to protect photosynthetic electron transport against subsequent low temperature stress in winter wheat. Plant Physiol. Biochem. 82, 34-43. doi: 10.1016/j.plaphy.2014.05.005

Logan, B. A. (2007). Chlorophyll a fluorescence: a signature of photosynthesis. J. Torrey Bot. Soc. 132, 650-650.

Long, A., Zhang, J., Yang, L. T., Ye, X., Lai, N. W., Tan, L. L., et al. (2017). Effects of low $\mathrm{pH}$ on photosynthesis, related physiological parameters, and nutrient profiles of citrus. Front. Plant Sci. 8:185. doi: 10.3389/fpls.2017.00185

Long, S. P., and Bernacchi, C. J. (2003). Gas exchange measurements, what can they tell us about the underlying limitations to photosynthesis? Procedures and sources of error. J. Exp. Bot. 54, 2393-2401. doi: 10.1093/jxb/erg262 
Lutts, S., and Lefèvre, I. (2015). How can we take advantage of halophyte properties to cope with heavy metal toxicity in salt-affected areas? Ann. Bot. 115, 509-528. doi: 10.1093/aob/mcu264

Lux, A., Martinka, M., Vaculík, M., and White, P. J. (2011). Root responses to cadmium in the rhizosphere: a review. J. Exp. Bot. 62, 21-37. doi: 10.1093/jxb/ erq281

Malik, D., Sheoran, I. S., and Singh, R. (1992). Carbon metabolism in leaves of cadmium treated wheat seedlings. Plant Physiol. Biochem. 30, 223-229. doi: $10.1104 /$ pp.98.3.1214

Marshall, B., and Biscoe, P. V. (1980). A model for C3 leaves describing the dependence of net photosynthesis on irradiance. 2. Application to the analysis of flag leaf photosynthesis. J. Exp. Bot. 31, 41-48. doi: 10.1093/jxb/31.1.41

Mathur, S., Jajoo, A., Mehta, P., and Bharti, S. (2015). Analysis of elevated temperature-induced inhibition of photosystem II using chlorophyll a fluorescence induction kinetics in wheat leaves (Triticum aestivum). Plant Biol. 13, 1-6. doi: 10.1111/j.1438-8677.2009.00319.x

Mcintyre, T. (2003). Phytoremediation of heavy metals from soils. Adv. Biochem. Eng. Biotechnol. 78, 97-123. doi: 10.1007/3-540-45991-X_4

Mehta, P., Jajoo, A., Mathur, S., and Bharti, S. (2010). Chlorophyll a fluorescence study revealing effects of high salt stress on Photosystem II in wheat leaves. Plant Physiol. Biochem. 48, 16-20. doi: 10.1016/j.plaphy.2009.10.006

Mobin, M., and Khan, N. A. (2007). Photosynthetic activity, pigment composition and antioxidative response of two mustard (Brassica juncea) cultivars differing in photosynthetic capacity subjected to cadmium stress. J. Plant Physiol. 164, 601-610. doi: 10.1016/j.jplph.2006.03.003

Monteiro, M. S., Santos, C., Soares, A. M. V. M., and Mann, R. M. (2009). Assessment of biomarkers of cadmium stress in lettuce. Ecotoxicol. Environ. Saf. 72, 811-818. doi: 10.1016/j.ecoenv.2008.08.002

Neubauer, C., and Schreiber, U. (1987). The polyphasic rise of chlorophyll fluorescence upon onset of strong continuous illumination: I. Saturation characteristics and partial control by the photosystem II acceptor side. Z. Naturforsch. C 42, 1246-1254. doi: 10.1515/znc-1987-11-1217

Nirupama, M., and Mohn, F. H. (2003). Use of chlorophyll fluorescence in metalstress research: a case study with the green microalga Scenedesmus. Ecotoxicol. Environ. Saf. 55, 64-69. doi: 10.1016/S0147-6513(02)00122-7

Nunes, C., Araújo, S. S., Silva, J. M., Fevereiro, P., and Silva, A. B. (2010). Photosynthesis light curves: a method for screening water deficit resistance in the model legume Medicago truncatula. Ann. Appl. Biol. 155, 321-332. doi: $10.1111 / \mathrm{j} .1744-7348.2009 .00341 . \mathrm{x}$

Omasa, K., and Takayama, K. (2003). Simultaneous measurement of stomatal conductance, non-photochemical quenching, and photochemical yield of photosystem II in intact leaves by thermal and chlorophyll fluorescence imaging. Plant Cell Physiol. 44, 1290-1300. doi: 10.1093/pcp/pcg165

Oukarroum, A., Bussotti, F., Goltsev, V., and Kalaji, H. M. (2015). Correlation between reactive oxygen species production and photochemistry of photosystems I and II in Lemna gibba L. plants under salt stress. Environ. Exp. Bot. 109, 80-88. doi: 10.1016/j.envexpbot.2014.08.005

Oukarroum, A., Madidi, S. E., Schansker, G., and Strasser, R. J. (2007). Probing the responses of barley cultivars (Hordeum vulgare L.) by chlorophyll a fluorescence OLKJIP under drought stress and re-watering. Environ. Exp. Bot. 60, 438-446. doi: 10.1016/j.envexpbot.2007.01.002

Pagliano, C., Raviolo, M., Vecchia, F. D., Gabbrielli, R., Gonnelli, C., Rascio, N., et al. (2006). Evidence for PSII donor-side damage and photoinhibition induced by cadmium treatment on rice (Oryza sativa L.). J. Photochem. Photobiol. B Biol. 84, 70-78. doi: 10.1016/j.jphotobiol.2006.01.012

Parmar, P., Kumari, N., and Sharma, V. (2013). Structural and functional alterations in photosynthetic apparatus of plants under cadmium stress. Bot. Stud. 54:45. doi: 10.1186/1999-3110-54-45

Peña-Rojas, K., Aranda, X., and Fleck, I. (2004). Stomatal limitation to $\mathrm{CO}_{2}$ assimilation and down-regulation of photosynthesis in Quercus ilex resprouts in response to slowly imposed drought. Tree Physiol. 24, 813-822. doi: 10.1093/ treephys/24.7.813

Per, T. S., Masood, A., and Khan, N. A. (2016). Nitric oxide improves S-assimilation and GSH production to prevent inhibitory effects of cadmium stress on photosynthesis in mustard (Brassica juncea L.). Nitric Oxide 68, 111-124. doi: 10.1016/j.niox.2016.12.012

Popova, L. P., Maslenkova, L. T., Yordanova, R. Y., Ivanova, A. P., Krantev, A. P., Szalai, G., et al. (2009). Exogenous treatment with salicylic acid attenuates cadmium toxicity in pea seedlings. Plant Physiol. Biochem. 47, 224-231. doi: 10.1016/j.plaphy.2008.11.007

Prioul, J. L., and Chartier, P. (1977). Partitioning of transfer and carboxylation components of intracellular resistance to photosynthetic $\mathrm{CO}_{2}$ fixation: a critical analysis of the methods Used. Ann. Bot. 41, 789-800. doi: 10.1093/ oxfordjournals.aob.a085354

Qian, H., Li, J., Sun, L., Chen, W., Sheng, G. D., and Liu, W. F. (2009). Combined effect of copper and cadmium on Chlorella vulgaris growth and photosynthesisrelated gene transcription. Aquat. Toxicol. 94, 56-61. doi: 10.1016/j.aquatox. 2009.05.014

Rascio, N., Vecchia, F. D., Rocca, N. L., Barbato, R., Pagliano, C., Raviolo, M., et al. (2008). Metal accumulation and damage in rice (cv. Vialone nano) seedlings exposed to cadmium. Environ. Exp. Bot. 62, 267-278. doi: 10.1016/j.envexpbot. 2007.09.002

Rizwan, M., Ali, S., Adrees, M., Ibrahim, M., Tsang, D. C. W., Zia-Ur-Rehman, M., et al. (2017). A critical review on effects, tolerance mechanisms and management of cadmium in vegetables. Chemosphere 182, 90-105. doi: 10. 1016/j.chemosphere.2017.05.013

Rupal, S. T., and Anjana, J. (2013). A quick investigation of the detrimental effects of environmental pollutant polycyclic aromatic hydrocarbon fluoranthene on the photosynthetic efficiency of wheat (Triticum aestivum). Ecotoxicology 22, 1313-1318. doi: 10.1007/s10646-013-1118-1

Sandalio, L. M., Dalurzo, H. C., Gomez, M., Romeropuertas, M. C., and Del, R. L. A. (2001). Cadmium-induced changes in the growth and oxidative metabolism of pea plants. J. Exp. Bot. 52, 2115-2126. doi: 10.1093/jexbot/52.364.2115

Santos, L. R., Batista, B. L., and Lobato, A. K. S. (2018). Brassinosteroids mitigate cadmium toxicity in cowpea plants. Photosynthetica 56, 591-605. doi: 10.1007/ s11099-017-0700-9

Schansker, G., Tóth, S. Z., and Strasser, R. J. (2005). Methylviologen and dibromothymoquinone treatments of pea leaves reveal the role of photosystem I in Chl a fluorescene rise OJIP. Biochim. Biophys. Acta 1706, 250-261. doi: 10.1016/j.bbabio.2004.11.006

Schansker, G., Tóth, S. Z., and Strasser, R. J. (2015). Dark recovery of the Chl a fluorescence transient (OJIP) after light adaptation: the qT-component of nonphotochemical quenching is related to an activated photosystem I acceptor side. Biochim. Biophys. Acta 1757, 787-797. doi: 10.1016/j.bbabio.2006.04.019

Shanying, H. E., Yang, X., Zhenli, H. E., and Baligar, V. C. (2017). Morphological and physiological responses of plants to cadmium toxicity: a review. Pedosphere 27, 421-438. doi: 10.1016/s1002-0160(17)60339-4

Sharkey, T. D., Bernacchi, C. J., Farquhar, G. D., and Singsaas, E. L. (2007). Fitting photosynthetic carbon dioxide response curves for $\mathrm{C} 3$ leaves. Plant Cell Environ. 30, 1035-1040. doi: 10.1111/j.1365-3040.2007.01710.x

Sheoran, I. S., Singal, H. R., and Singh, R. (1990). Effect of cadmium and nickel on photosynthesis and the enzymes of the photosynthetic carbon reduction cycle in pigeonpea (Cajanus cajan L.). Photosynth. Res. 23, 345-351. doi: 10.1007/ bf00034865

Shukla, U. C., Murthy, R. C., and Kakkar, P. (2008). Combined effect of ultraviolet- $\mathrm{B}$ radiation and cadmium contamination on nutrient uptake and photosynthetic pigments in Brassica campestris L. seedlings. Environ. Toxicol. 23, 712-719. doi: 10.1002/tox.20378

Siedlecka, A., Samuelsson, G., Gardeström, P., Kleczkowslci, L. A., and Krupa, Z. (1998). "The "Activatory Model” of plant response to moderate cadmium stress - relationship between carbonic anhydrase and rubisco," in Photosynthesis: Mechanisms and Effects, ed. G. Garab (Dordrecht: Springer). doi: 10.1007/978-94-011-3953-3_630

Singh, S., Khan, N. A., Nazar, R., and Anjum, N. A. (2008). Photosynthetic traits and activities of antioxidant enzymes in blackgram (Vigna mungo L. Hepper) under cadmium stress. Am. J. Plant Physiol. 3, 25-32. doi: 10.3923/ajpp.2008. 25.32

Somashekaraiah, B. V., Padmaja, K., and Prasad, A. R. K. (1992). Phytotoxicity of cadmium ions on germinating seedlings of mung bean (Phaseolus vulgaris): involvement of lipid peroxides in chlorphyll degradation. Physiol. Plant. 85, 85-89. doi: 10.1111/j.1399-3054.1992.tb05267.x

Song, X., Zhou, G., Xu, Z., Lv, X., and Wang, Y. (2016). A self-photoprotection mechanism helps Stipa baicalensis adapt to future climate change. Sci. Rep. 6:25839. doi: 10.1038/srep25839

Stephen, E., Mottram, D. S., Nira, M., Dodson, A. T., Parry, M. A. J., and Halford, N. G. (2007). Changes in free amino acids and sugars in potatoes due to sulfate 
fertilization and the effect on acrylamide formation. J. Agric. Food Chem. 55, 5363-5366. doi: 10.1021/jf070447s

Strasser, R. J., and Govindjee (1992). The FO and the O-J-I-P Fluorescence Rise in Higher Plants and Algae. Heidelberg: Springer. doi: 10.1007/978-1-4615-3366560

Strasser, R. J., Tsimilli-Michael, M., and Srivastava, A. (2004). Analysis of the Chlorophyll a Fluorescence Transient. Dordrecht: Springer. doi: 10.1007/978-14020-3218-9_12

Strauss, A. J., Krüger, G. H. J., Strasser, R. J., and Heerden, P. D. R. V. (2006). Ranking of dark chilling tolerance in soybean genotypes probed by the chlorophyll a fluorescence transient O-J-I-P. Environ. Exp. Bot. 56, 147-157. doi: 10.1016/j.envexpbot.2005.01.011

Su, J. W., and Wang, X. P. (2004). Effect of Cadmium ions on photosynthetic structure and its functions of tea leaves. J. Tea Sci. 24, 65-69. doi: 10.13305/j. cnki.jts.2004.01.013

Sun, Z. W., Ren, L. K., Fan, J. W., Li, Q., Wang, K. J., Guo, M. M., et al. (2016). Salt response of photosynthetic electron transport system in wheat cultivars with contrasting tolerance. Plant Soil Environ. 62, 515-521. doi: 10.17221/529/ 2016-PSE

Tartachnyk, I. I., and Blanke, M. M. (2004). Effect of delayed fruit harvest on photosynthesis, transpiration and nutrient remobilization of apple leaves. New Phytol. 164, 441-450. doi: 10.1111/j.1469-8137.2004.01197.x

Tongra, T., Mehta, P., Mathur, S., Agrawal, D., Bharti, S., Los, D. A., et al. (2011). Computational analysis of fluorescence induction curves in intact spinach leaves treated at different pH. Biosystems 103, 158-163. doi: 10.1016/ j.biosystems.2010.07.019

Vartika, R., Sayyada, K., Bisht, S. S., and Shanta, M. (2005). Effect of cadmium on growth, ultramorphology of leaf and secondary metabolites of Phyllanthus amarus Schum. and Thonn. Chemosphere 61, 1644-1650. doi: 10.1016/j. chemosphere.2005.04.052

Voigt, J., and Nagel, K. (2002). The donor side of photosystem II is impaired in a $\mathrm{Cd}^{2+}$-tolerant mutant strain of the unicellular green alga Chlamydomonas reinhardtii. J. Plant Physiol. 159, 941-950. doi: 10.1078/0176-1617-00705

Wahid, A., Ghani, A., Ali, I., and Ashraf, M. Y. (2010). Effects of Cadmium on carbon and nitrogen assimilation in shoots of mungbean [Vigna radiata (L.) Wilczek] seedlings. J. Agron. Crop Sci. 193, 357-365. doi: 10.1111/j.1439-037X. 2007.00270.x

Wali, M., Fourati, E., Hmaeid, N., Ghabriche, R., Poschenrieder, C., Abdelly, C., et al. (2015). $\mathrm{NaCl}$ alleviates $\mathrm{Cd}$ toxicity by changing its chemical forms of accumulation in the halophyte Sesuvium portulacastrum. Environ. Sci. Pollut. Res. Int. 22, 10769-10777. doi: 10.1007/s11356-015-4298-9

Wali, M., Gunsè, B., Llugany, M., Corrales, I., Abdelly, C., Poschenrieder, C., et al. (2016). High salinity helps the halophyte Sesuvium portulacastrum in defense against Cd toxicity by maintaining redox balance and photosynthesis. Planta 244, 1-14. doi: 10.1007/s00425-016-2515-5

Wali, M., Martos, S., Pérez-Martín, L., Abdelly, C., Ghnaya, T., Poschenrieder, C., et al. (2017). Cadmium hampers salt tolerance of Sesuvium portulacastrum. Plant Physiol. Biochem. 115, 390-399. doi: 10.1016/j.plaphy.2017.04.014

Walker, A. P., Beckerman, A. P., Gu, L., Kattge, J., Cernusak, L. A., Domingues, T. F., et al. (2015). The relationship of leaf photosynthetic traits - Vcmax and Jmax - to leaf nitrogen, leaf phosphorus, and specific leaf area: a meta-analysis and modeling study. Ecol. Evol. 4, 3218-3235. doi: 10.1002/ece3.1173

Wu, Z., Zhao, X., Sun, X., Tan, Q., Tang, Y., Nie, Z., et al. (2015). Antioxidant enzyme systems and the ascorbate-glutathione cycle as contributing factors to cadmium accumulation and tolerance in two oilseed rape cultivars (Brassica napus L.) under moderate cadmium stress. Chemosphere 138, 526-536. doi: 10.1016/j.chemosphere.2015.06.080

Wullschleger, S. D. (1993). Biochemical limitations to carbon assimilation in C3 plants-A retrospective analysis of the A/Ci curves from 109 Species. J. Exp. Bot. 44, 907-920. doi: 10.1093/jxb/44.5.907

$\mathrm{Xu}$, L. L., Dong, Y. J., Kong, J., and Liu, S. (2014). Effects of root and foliar applications of exogenous NO on alleviating cadmium toxicity in lettuce seedlings. Plant Growth Regul. 72, 39-50. doi: 10.1007/s10725-013-98 34-3

Yasemin, E. I., Deniz, T., and Beycan, A. (2008). Effects of cadmium on antioxidant enzyme and photosynthetic activities in leaves of two maize cultivars. J. Plant Physiol. 165, 600-611. doi: 10.1016/j.jplph.2007.01.017

Yu, Y., Wan, Y., Wang, Q., and Li, H. (2017). Effect of humic acid-based amendments with foliar application of $\mathrm{Zn}$ and $\mathrm{Se}$ on $\mathrm{Cd}$ accumulation in tobacco. Ecotoxicol. Environ. Saf. 138, 286-291. doi: 10.1016/j.ecoenv.2017. 01.011

Zhang, X., Zhang, X., Gao, B., Li, Z., Xia, H., Li, H., et al. (2014). Effect of cadmium on growth, photosynthesis, mineral nutrition and metal accumulation of anenergy crop, king grass (Pennisetum americanum $\times$ P. purpureum). Biomass Bioenergy 67, 179-187. doi: 10.1016/j.biombioe.2014. 04.030

Zhang, Y., Xu, S., Yang, S., and Chen, Y. (2015). Salicylic acid alleviates cadmium-induced inhibition of growth and photosynthesis through upregulating antioxidant defense system in two melon cultivars (Cucumis melo L.). Protoplasma 252, 911-924. doi: 10.1007/s00709-0140732-y

Zhao, F. J., Lombi, E., and Mcgrath, S. P. (2003). Assessing the potential for zinc and cadmium phytoremediation with the hyperaccumulator Thlaspi caerulescens. Plant Soil 249, 37-43. doi: 10.1023/a:1022530217289

Zhao, L. J., Xie, J. F., Zhang, H., Wang, Z. T., Jiang, H. J., and Gao, S. L. (2018). Enzymatic activity and chlorophyll fluorescence imaging of maize seedlings (Zea mays L.) after exposure to low doses of chlorsulfuron and cadmium. J. Integr. Agric. 17, 826-836. doi: 10.1016/\$2095-3119(17) 61717-9

Zhou, H. H., Chen, Y. N., Li, W. H., and Chen, Y. P. (2010). Photosynthesis of Populus euphratica in relation to groundwater depths and high temperature in arid environment, northwest China. Photosynthetica 48, 257-268. doi: 10.1007/ s11099-010-0032-5

Zhu, X., Ort, D. R., Whitmarsh, J., and Long, S. P. (2004). The slow reversibility of photosystem II thermal energy dissipation on transfer from high to low light may cause large losses in carbon gain by crop canopies: a theoretical analysis. J. Exp. Bot. 55, 1167-1175. doi: 10.1093/jxb/erh141

Conflict of Interest Statement: The authors declare that the research was conducted in the absence of any commercial or financial relationships that could be construed as a potential conflict of interest.

Copyright (c) 2019 Song, Yue, Chen, Jiang, Han and Li. This is an open-access article distributed under the terms of the Creative Commons Attribution License (CC BY). The use, distribution or reproduction in other forums is permitted, provided the original author(s) and the copyright owner(s) are credited and that the original publication in this journal is cited, in accordance with accepted academic practice. No use, distribution or reproduction is permitted which does not comply with these terms. 